\title{
CORYNOTRYPA, A NEW GENUS OF TUBULIPOROID BRYOZOA.
}

\author{
By Ray S. Bassler,
}

Curator of Invertebrate Paleontology, U. S. National Museum.

\section{INTRODUCTION.}

The present paper discusses all the known species of a supposed new genus of simple tubuliporoid Bryozoa, and may be said, therefore, to be monographic in its scope. However, the prime object of the article is the determination of the specific variation in a group of tubular organisms, which, on account of their minute size and extreme simplicity as well as alleged great variability of structure, have presented difficulties of classification.

In almost every class of natural history in which tubular organisms occur, the classification of these simpler types has proved more difficult than that of their more complicated allies. This is particularly true in the case of the Bryozoa where the simplest of such tubular forms are grouped under the family Tubuliporidæ, in the order Cyclostomata. A wide difference of opinion has obtained even among the best students as to the classificatory value of the few and supposedly quite variable characters exhibited by these types, and their literature therefore presents varying degrees of exactness. For example, Waters, an excellent but very conservative student, considered the early Ordovician form Mitoclema cinctosum to be the same as the late Mesozoic Spiropora verticillata, while Haime included in one species specimens which d'Orbigny had divided among five genera. In spite of such extreme views there is a growing tendency among present-day students to recognize as genera in these simple bryozoans those groups, distinguished mainly by method of growth, around which the various species may be assembled. Gregory ${ }^{a}$ has given an interesting discussion on the value of generic divisions in the Cyclostomata, arriving at the conclusion that the terms Stomatopora, Proboscina, and like names applied to the simple bryozoans, might be accepted, not as generic names in the sense in which this term is used in the higher groups of animals, but as designations for convenient groups not altogether artificial. He says: "They could

$a$ Cat. Foss. Bryozoa British Museum, The Jurassic Bryozoa, 1896, pp. 14-22.

Proceedings U. S. National Museum, Vol. 39-No. 1797.

Proc.N.M.vol.39-10-34 
be better described as circuli than as genera. A circulus was one of the small groups of individuals who clustered round speakers in the Roman forum. Most of the individuals in the forum were definitely attached to a particular group; the groups were less crowded around their margins, and between them people were irregularly scattered and crossed from circulus to circulus. They thus prevented any rigid division of the crowd into definite groups."

While Gregory's view of genera among the simple Cyclostomata is a very ingenious one, still it seems to me that no distinction need be made between the conception of a genus of Bryozoa and that of any other group of organisms. It must always be recognized that sharply outlined genera are impossible in any class, and that generic names are instituted for convenience in designating a series of organisms having certain characters in common, as well as to show natural affinity. The middle forms of such a series will have the most distinctive characters, while those at either end often show relationships to allied groups of species.

The simplest of the tubuliporoid bryozoans comprise the forms in which the zoœcia are adnate and arranged uniserially. To-day most writers restrict the genus Stomatopora Bronn to such unilinear species. More complex, adnate species have the zoœcia arranged in two or more rows and are generally referred to the genus Proboscina Audouin, while zoaria of incrusting circular or irregular patches, resulting from the union of numerous contiguous zoœcia, belong to Lamouroux's genus Berenicea. The present article deals only with simple, unilinear forms, which, as stated above, have hitherto been classed as Stomatopora.

My experience with Stomatopora began some years ago with the two very abundant Ordovician forms, $S$. arachnoidea and $S$. inflata Hall. These two species are so different that I could never reconcile their recognition as species of the same genus; but it is only recently that sufficient material has been accumulated in the collections of the U. S. National Museum to warrant a close study of the subject. Now all of the known Paleozoic and most of the Mesozoic and later forms of the genus are represented by specimens, and of many of them the material is abundant enough to fairly test their hitherto commonly supposed great instability in specific characters. The present paper is therefore based upon a study of thousands of specimens from widely separated localities and from many horizons in the geologic column.

The two Ordovician species mentioned above being the most numerously represented, received a correspondingly greater amount of study. S. arachnoidea is essentially like the Jurassic S. dichotoma, the genotype of Stomatopora, but the zoœcia of $S$. inflata are so different and its peculiarities are so constantly reproduced in a long line of descendants, that it seems desirable to establish a new genus 
for them. Thus, while the typical forms of Stomatopora have zoœcia with more or less parallel sides and no narrow, elongated, proximal portion, and large, open, exsert apertures, the new genus comprises the uniserial, adnate tubuliporoids in which the individual zoœcia are contracted at their proximal end and rounded at the distal or apertural portion. The latter type of structure pertains to species ranging from the base of the Ordovician to the close of the Mesozoic, and the known representatives are divisible into no less than sixteen species. Considering these facts and also that the species are always easily distinguished from the typical forms of Stomatopora, I propose for them the new name Corynotrypa, in reference to the club-shaped
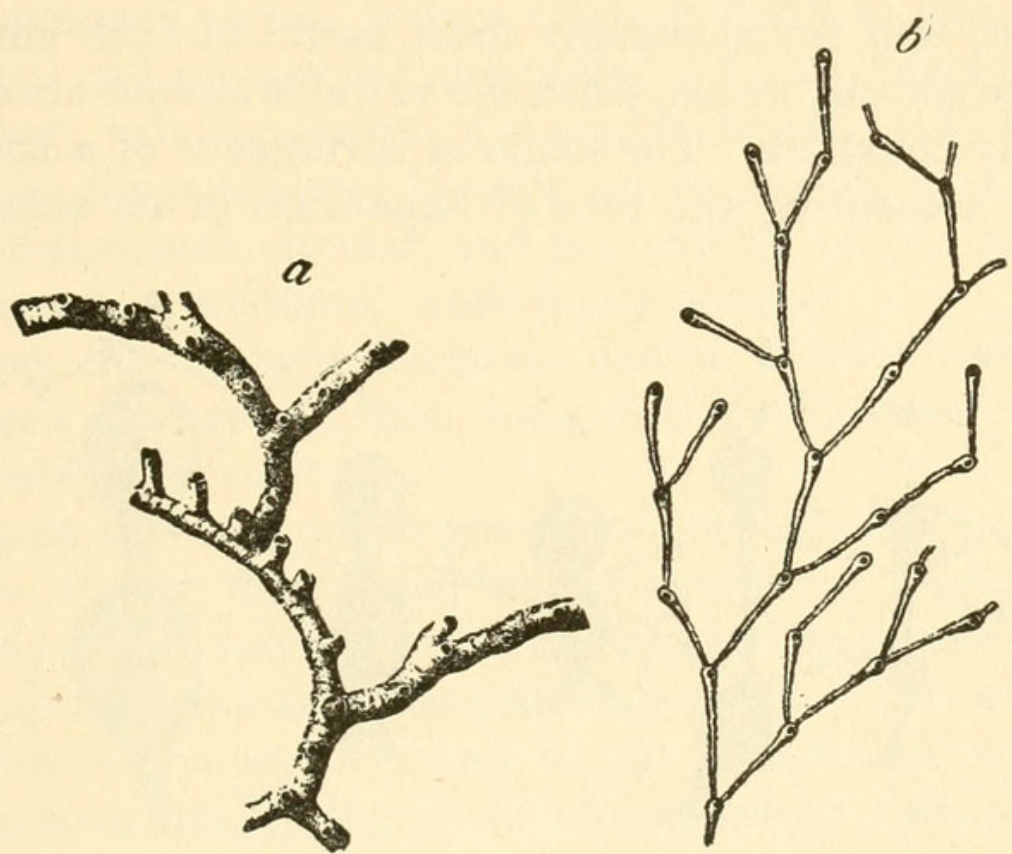

Fig. 1.-Genotypes of Stomatopora and CoRYNotrypa, illustrating generic differences. $a$, Stomatopora dichotoma. Jurassic, Hampton Cliffs, England. (After Haime.) b, Corynotrypa delicatula. Upper Ordoviclan, Cincinnati, OHio. (After Ulrich.)

zoœcium with the perforation or zoœcial aperture at its swollen end. The differences between the genus Stomatopora as thus restricted and the new genus Corynotrypa are brought out in figure 1.

\section{TERMINOLOGY.}

On account of the great simplicity of the clavate zoœcia, and the constant difficulty in discriminating closely allied forms, it has been found useful to employ the following terms in their descriptions. The slender, proximal portion ( $s$ ) of the zoœcium (figure 2 ), ${ }^{a}$ is seen to vary

$a$ All of the original illustrations in this paper have been prepared by Miss Frances Wieser from camera lucida sketches drawn by the author. Great care has been taken to secure exactness of measurement, especially in the angle of divergence. Whenever a specimen did not show its characters clearly under the microscope, it was whitened by one of the several processes employed for this purpose. A thin coat of some white substance applied to apparently indistinct specimens often brings out their structure with astonishing clearness. 
greatly in length, indeed a considerable variation exists in individual zoœcia of the same zoarium. For convenience this portion is called the stolon. The true zoœcial, and therefore specific characters can be expressed only in those portions of the zoarium lodging mature animals. Obviously the slender stolons of the typical species of Corynotrypa could not lodge normal polypides, and this portion is consequently deemed of subordinate specific value. The stolon may be said to correspond to the immature zone of a zoœcium in a trepostomatous bryozoan. The normal polypide undoubtedly was limited to the expanded portion of the zoœcium $(z)$ which is here designated as the zoœcium proper or simply the zoœcium. This portion has several characteristics which are very constant within specific limits. First, and taxonomically most useful of such characters, is the size of the zoœcia, which, when the variable stolons are eliminated, is remarkably constant. The angle of divergence of a zoœcium $(g)$, obtained by measuring the rate of expansion of its sides from the

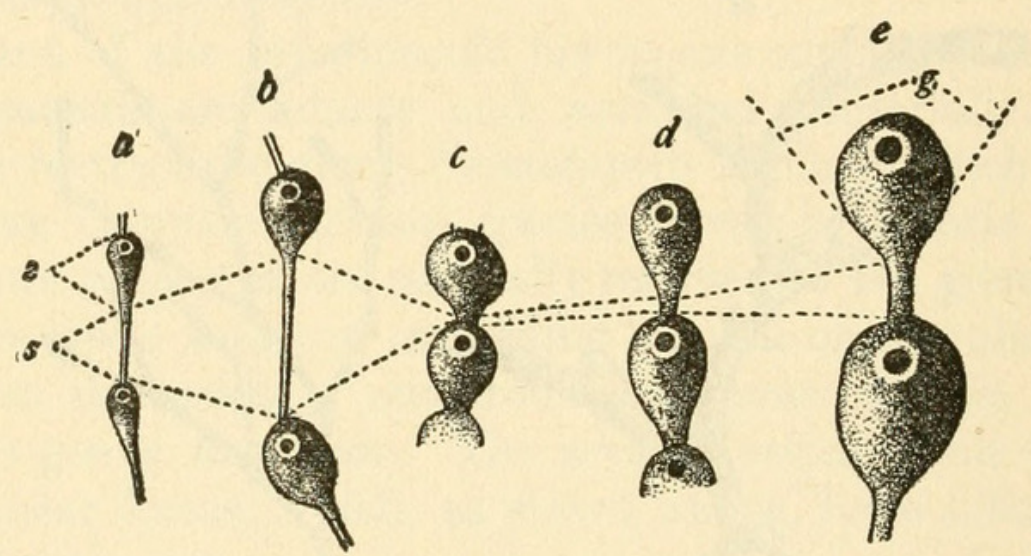

Fig. 2.-Characteristic SPECIES OF Corýnotrypa, $\times 20$, illustrating Variation in Stolon $(s)$ ZOGCIUM PROPER $(z)$, AND ANGLE OF DIVERGENCE $(g)$. $a$, CoRYNOTRYPA DELICATUla; $b$, C. ABRUPTA; $c$, C. curta; $d$, C. inflata; $e$, C. Turgida.

distal end of the stolon, has likewise proved of much value in identifying the different types. Less useful criteria, and generic rather than specific in significance, are the position and relative size of the zoœcial aperture and its encircling peristome. As a rule the aperture is subterminal and has a diameter about one-third that of the zoœcium at its greatest width. The walls are similarly porous in this as well as in many other cyclostomatous genera, so that the minute structure of the walls offers little help in distinguishing either species or genera. However, one section of Corynotrypa contains species in which the walls are transversely wrinkled so that the character of the zoœcial surface is, therefore, not to be entirely ignored.

In brief, then, after determining from its uniserial growth and clavate zoœcia that a form belongs to this new genus, the species may be determined almost wholly by the size and general outline of the zoœcium proper, and, under the latter, especially by its angle of 
divergence. The differences, while often very slight, hold so well that little difficulty is encountered in recognizing species the world over. For example, the genotype, Corynotrypa delicatula, and the well-known $C$. inflata, so common in numerous Ordovician horizons of America, have been recognized at several European localities. C. abrupta, C. dissimilis, C. barberi, and $C$. elongata are likewise nearly cosmopolitan forms.

With these points of terminology in mind, the genus may be defined as follows:

CORYNOTRYPA, new genus.

Zoarium adnate, consisting of simple, subtubular zoœcia arranged in single-branched series; zoœcia oval-pyriform to elongate clavate, the proximal end constricted and united with the preceding zoœcium by a narrow, tubular stolon of variable length; the distal portion more or less expanded and bearing on its frontal side the aperture which is subterminal, circular, and inclosed by a more or less distinct, slightly elevated peristome; walls finely porous.

Genotype, Stomatopora delicatula James. Ordovician of America and Europe. Range of genus, base of Ordovician to close of Mesozoic; probably also Cenozoic.

The closest ally of Corynotrypa is undoubtedly the well-known and even more widely distributed and longer-lived Stomatopora. The two genera agree in having an incrusting zoarium composed of simple, porous, tubular zoœcia arranged uniserially. Corynotrypa differs from Stomatopora most obviously in the constriction of the proximal end of the zoœcium, giving it the characteristic clavate to pyriform shape which causes each to stand out as an individual. In Stomatopora the successive zoœcia form a narrow branch with more or less parallel sides in which the individuals are scarcely delimitable except by their apertural openings.

Among the species referred to Corynotrypa, the proximal constriction is most evident in those assigned to the $C$. inflata and the $C$. delicatula groups discussed later, but becomes less marked in such forms as $C$. canadensis and $C$. dissimilis. The last two represent a third group in which the generic relationship to Stomatopora is much more obvious. In addition to the shape of the zoœcium, the aperture in Corynotrypa likewise presents good generic characters. In typical Stomatopora the aperture is exsert, usually slightly tilted forward, and often almost equals the zoarial branch in diameter. Corynotrypa, in its two principal groups, has a small, neatly constricted aperture, never exsert, with a width about one-third that of the branch and surrounded by a low but distinctly marked peristome. In the third or $C$. dissimitis group of Corynotrypa, the nearer relation to Stomatopora is again expressed, in that the zoccial apertures are occasionally exsert and of unusual width. 
Altogether it is believed that the club-shaped zoœcia produced by the constriction of the proximal end, and the small, neatly constricted aperture with low peristomes, constitute sufficient characters to justify a new genus, although it is recognized that several intermediate forms exist between this genus and Stomatopora, as here restricted.

This new cyclostomatous genus, in its method of growth and general shape of the zoœcia is quite similar to genera of other orders, an occurrence which is not unusual in the Bryozoa. Such species as Corynotrypa nitida or $C$. tenuichorda are exceedingly like elongate, delicate forms of Hippothoa, and might readily be confused. The latter genus, however, a representative of the Chilostomata, has a sinus in the lower margin of the aperture and an occasional well-marked oœcium, as well as a very delicate surface ornamentation quite different, on close examination, from the simple punctate structure of Corynotrypa. Among the Ctenostomata such genera as the recent Arachnidium and the fossil Rhopalonaria are so similar in general shape to Corynotrypa that at least one species of the last genus was originally referred to the second.

\section{GEOLOGIC DISTRIBUTION.}

The geographic distribution of Corynotrypa has been briefly indicated in previous remarks, and is also shown in the description of the species. Regarding its geologic range, it is interesting to note that the two typical sections of the genus show a somewhat parallel specific development. Thus, in the Ordovician, the most abundant, $C$. delicatula, with a long geologic range, is accompanied through a considerable part of this time by the equally abundant $C$. inflata. During earliest Silurian, when the deposits of the Richmond group were being laid down, conditions seem to have been favorable for the development or introduction of new, somewhat bizarre species, which apparently did not survive for any great length of time. Among these are the unusually large, swollen form, C. turgida, another equally well marked species, C. curta, differing, however, in being exceptionally small and short, and, lastly, C. abrupta, with a long, slender stolon and short, greatly swollen zoœcium.

In the Silurian, succeeding Richmond time, no representative of the $C$. inflata section has been discovered so far, but the Devonian contains a delicate species of each section. The next known occurrence of the genus is in the Mesozoic, where, as shown in the table on page 504, again a single species of each section appears. The apparent absence of the genus in the known Mississippian, Pennsylvanian, and Permian rocks may be due to lack of systematic search, but it is nevertheless a curious fact that all of the simple cyclostomatous 
bryozoans have a similar geologic distribution. Stomatopora, Proboscina, Berenicea, and other genera, although well developed before and after, have no known representative during Carboniferous time.

\section{VARIATIONAL FORMULAS.}

The extreme variability of these simple Cyclostomata has been recognized by many writers, with the result that the conception of a species has often changed with each author's study. Gregory has recognized this variation and has suggested the identification of species by means of variational formulæ. For the simple, incrusting forms, such as those discussed in this paper, he uses four main features, namely, the character of the peristome, the shape of the zoœcia, the length of the zoœcia, and, finally, the general aspect of the zoariuin. Thus, for Stomatopora, the terms of his formula are as follows:

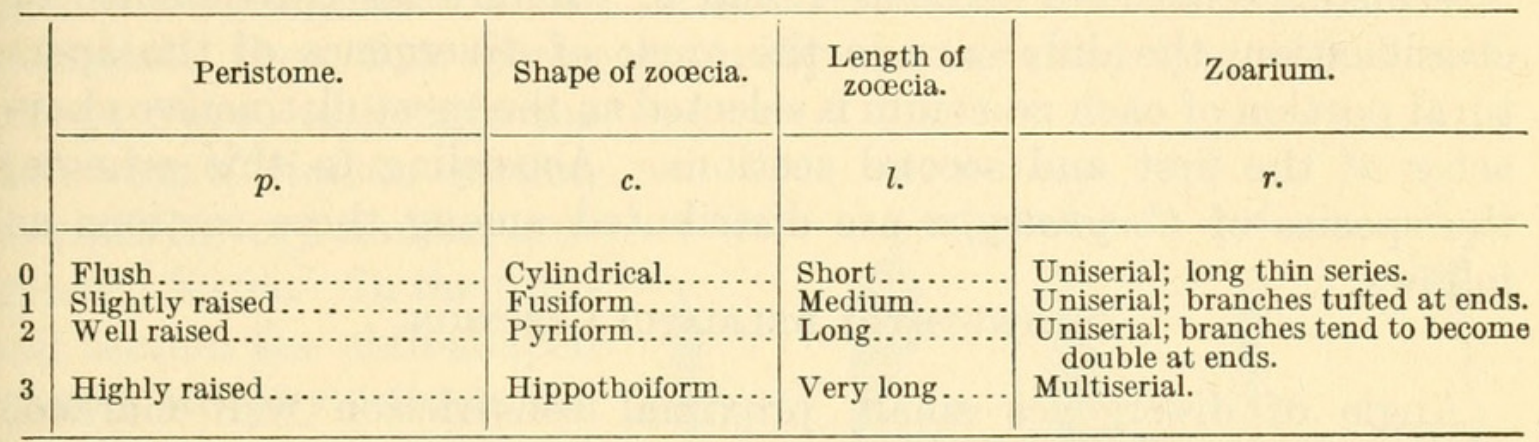

Applying his method to Stomatopora dichotoma (Lamouroux), illustrated on page 499, its formula would be as follows:

$$
\text { Stomatopora dichotoma (Lamouroux) }=\frac{p \cdot c}{2} \frac{c .}{0} \frac{r}{1} \frac{r}{1}
$$

However, a new scheme would be necessary for the species formerly assigned to Stomatopora but here described as Corynotrypa, since two of the terms - the length and outline of zoœcia, including the stolonvary considerably in the same species, and the two remaining terms, the peristome and the zoarium, are practically always the same. For example, the formula for Corynotrypa inflata, as illustrated in figures 12 and 13 , would be as below:

$$
\text { Corynotrypa inflata }(\mathrm{Hall})=\frac{p .}{1} \frac{c .}{1-2-3} \frac{l .}{0-1-2-3} \frac{r}{0}
$$

Of course it is recognized that the latter is an extreme case and that the formula for this species should be based upon normal zoœcia only, as shown in figure $2 d$. The terms of the formula quoted above probably will serve very well for species of the genus Stomatopora as here restricted.

For Corynotrypa, it is believed that a division into three sections, based mainly upon the angle of divergence of the zoœcial walls, is preferable and of more value in the identification of species. 


\section{SUBDIVISIONS OF CORYNOTRYPA.}

Three fairly distinct subdivisions of Corynotrypa may be recognized, with, however, one or more intermediate species connecting them. These, from their most characteristic species, may be known as (1) the $C$. delicatula section, with long, exceedingly slender zoœcia enlarging very slowly and always remaining quite narrow at the apertural portion; (2) the $C$. inflata section, in which the zoœcia enlarge rapidly after the slender, proximal stage is passed; and (3) the $C$. dissimilis section, with broad, stout, little constricted zoœcia and often distinguished in addition by a surface ornamentation of transverse lines. At least two quite dissimilar species, $C$. schucherti and $C$. canadensis, are known, connecting the second and third sections, while another well-marked form, $C$. barberi, appears to be intermediate between sections 1 and 2. Merely for convenience of classification, the difference in the angle of divergence of the apertural portion of each zoœcium is selected as the most distinctive character of the first and second sections. According to this scheme, the species of Corynotrypa are distributed among these sections as follows:

CORYNOTRYPA DELICATULA SECTION.

Angle of divergence small, proximal constriction well marked, aperture constricted and with peristome.

\begin{tabular}{|c|c|c|}
\hline Species. & $\begin{array}{c}\text { Angle of } \\
\text { divergence. }\end{array}$ & Geologic range. \\
\hline 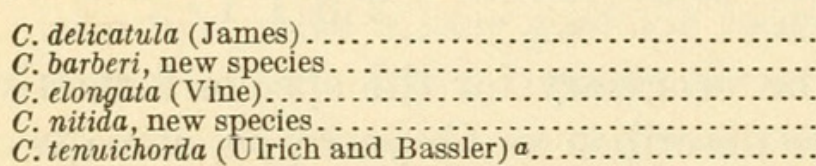 & $\begin{array}{l}15^{\circ} \\
30^{\circ} \\
25^{\circ} \\
20^{\circ} \\
30^{\circ}\end{array}$ & $\begin{array}{l}\text { Ordovician and early Silurian. } \\
\text { Do. } \\
\text { Silurian. } \\
\text { Devonian. } \\
\text { Cretaceous. }\end{array}$ \\
\hline
\end{tabular}

$a$ Several of the Cretaceous species of Stomatopora, figured by d'Orbigny in the fifth volume of Paleontologie Francaise, appear to have the characters of Corynotrypa, but in view of that author's diagrammatic and frequently incorrect illustrations I have hesitated to refer them to the genus without a study of actual specimens.

CORYNOTRYPA INFLATA BECTION.

Angle of divergence great, proximal constriction well marked, aperture constricted and with peristome.

\begin{tabular}{|c|c|c|}
\hline Species. & $\begin{array}{c}\text { Angle of } \\
\text { divergence. }\end{array}$ & Geologic range. \\
\hline 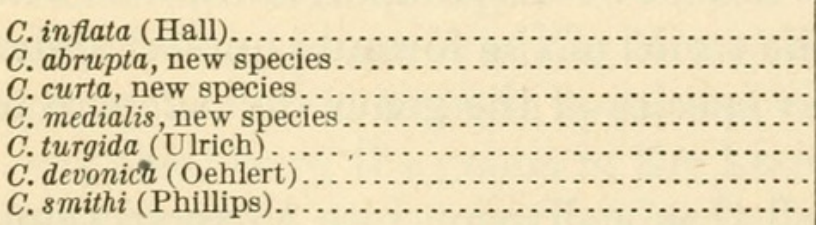 & $\begin{array}{l}40^{\circ} \\
50^{\circ} \\
70^{\circ} \\
50^{\circ} \\
70^{\circ} \\
40^{\circ} \\
40^{\circ}\end{array}$ & $\begin{array}{l}\text { Ordovician and early Silurian. } \\
\text { Early Silurian. } \\
\text { Do. } \\
\text { Do. } \\
\text { Do. } \\
\text { Devonian. } \\
\text { Jurassic. }\end{array}$ \\
\hline
\end{tabular}


CORYNOTRYPA DISSIMILIS SECTION.

Angle of divergence very small, proximal constriction less distinctly marked, aperture slightly exsert, little constricted, walls transversely wrinkled or smooth.

\begin{tabular}{|c|c|}
\hline Species. & Geologic range. \\
\hline $\begin{array}{l}\text { C. dissimilis (Vine) } \\
\text { C.tennesseensis, new species..... } \\
\text { C. schucherti, new species........ } \\
\text { C. canadensis (Whiteaves)....... }\end{array}$ & $\begin{array}{l}\text { Silurian. } \\
\text { Ordovician. } \\
\text { Do. } \\
\text { Do. }\end{array}$ \\
\hline
\end{tabular}

CORYNOTRYPA DELICATULA SECTION.

At least four species are known with characters so similar to the genotype that they may be grouped with it into a section of the genus as designated above. On account of their relations to $C$. delicatula, these five species naturally are the most typical forms of Corynotrypa, although the following $C$. inflata section comprises very similar, congeneric forms. In the present section the club-shaped zoœcia are very delicate and usually greatly elongated, the slender stolon being almost always well developed. The angle of divergence in the zoœcia proper is so slight that some care is required to determine the distal end of the stolon. This angle is about $15^{\circ}$ in $C$. delicatula, and ranges from this to $30^{\circ}$

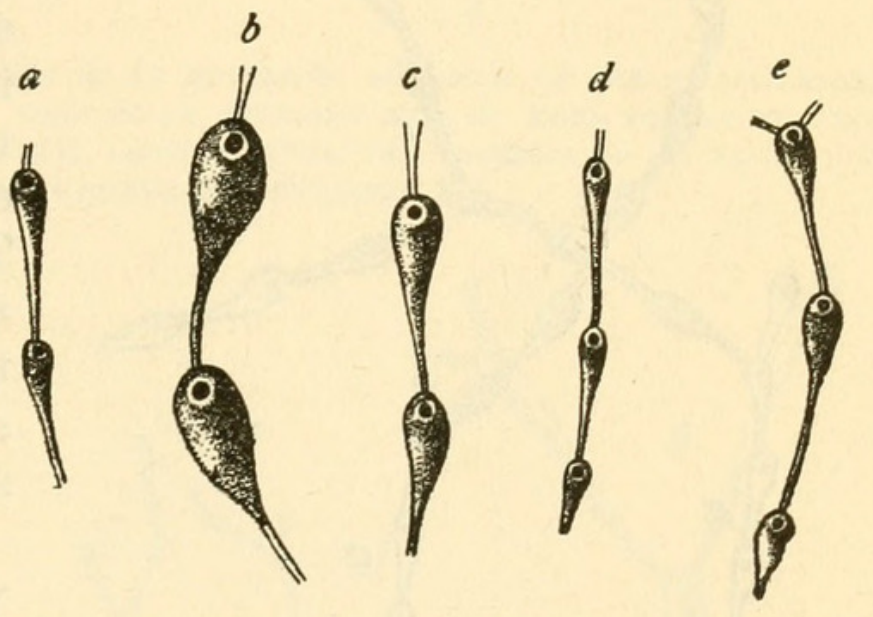

Fig. 3.-Corynotrypa delicatula section. Group oy ZOCEIA, $\times 20$, SHOWING SPECIFIC DIFFERENCES. $a$, CORYNOTRYPA DELICATULA; $b$, C. BARBERI; $c$, C. ELONGATA; $d$, C. NITIDA; $e$, C. TENUICHORDA.

in other species of the section. The aperture in both this and the C. inflata section agrees in being constricted, with a diameter about one-third that of the zoœcium, and in being surrounded by a distinct peristome. Views of average zoœcia, equally magnified, of the five species referred to this section of the genus, are assembled in figure 3 for convenience of comparison.

Specific variation.-For reasons which will shortly be apparent, this section exhibits an astonishing amount of variation in the same species. This has been studied in only the type species on account of abundant material, but similar variation will no doubt be found in the other members of the section. Indeed, the variation is so great in $C$. delicatula that at least four distinct names have been applied to the species. The types, or typical specimens of these 
four are in the collections of the U. S. National Museum, and their study, in connection with numerous other examples, soon revealed the fact that this extreme variation is due, not to the zoœcium proper, but to the stolon. Single zoaria were found exhibiting, in individual zoœcia, all the differences attributed to the supposed four distinct species. Such a zoarium is shown in figure 4, in which the usual relation between the length of the stolon and the zoœcium

proper is shown at $a$. At $b$ the

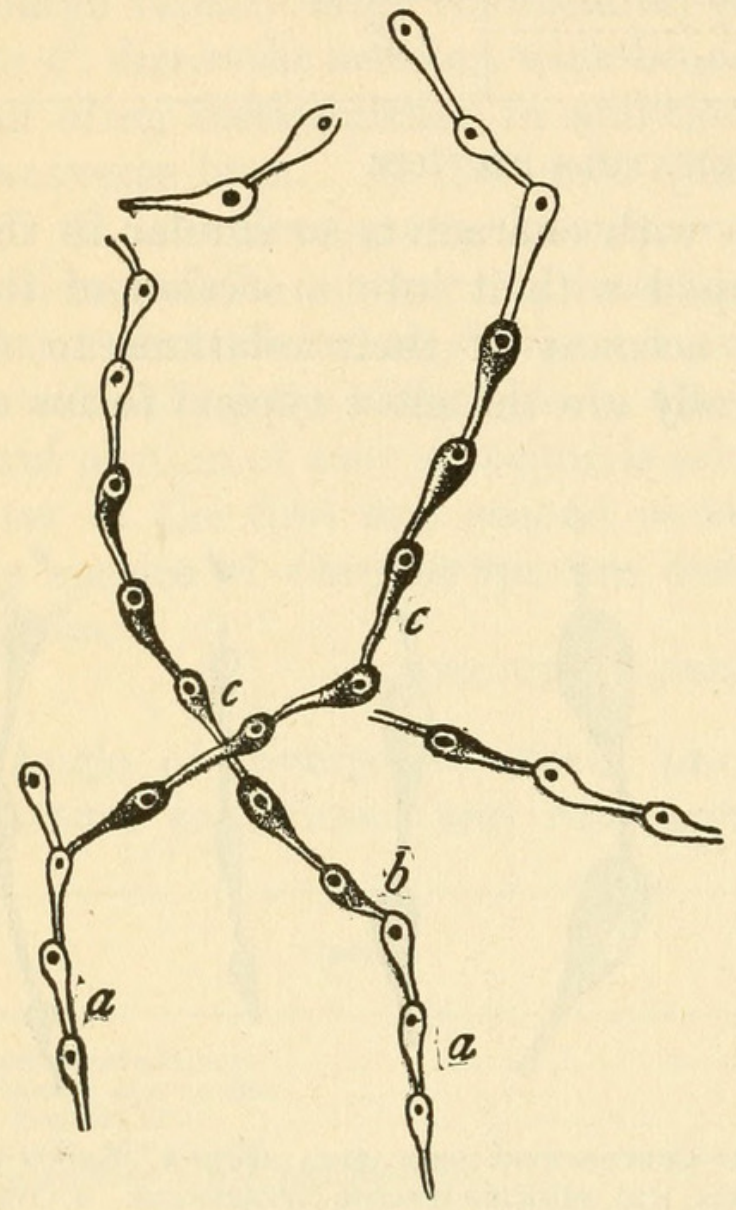

Fig. 4.-Corynotrypa delicatula. ZoArium, $\times 12$ ILLUSTRATING VARIABLE LENGTH OF STOLON. ORDOVICIAN, CORRYVILle bEDS OF MCMILlaN FORMation, Cincinnati, Uhio. For lettering SeE TEXT. stolon is almost entirely absent, but the zoœcium has the normal shape, size, and angle of divergence. However, zoœcia in the same linear series, as at $c$, may develop stolons of considerable length. It will be observed in each of these cases that the size and shape of the zoœcium proper, and its angle of divergence, in addition to such characters as the position and size of the aperture, has remained constant. The stolon is obviously the variable character, and, eliminating it, one can not attribute such unusual variability to these simple types as has been done.

The cause of this variable development of the stolon seems to be a purely physical one, due almost entirely to the habitat of the species. For instance, again using the example figured above, the zoœcia at $a$ are incrusting a smooth plane surface; at $b$ there is a depression just wide enough to accommodate a short zoœcium, while at $c$ the surface is slightly roughened, and the zoœcium, to avoid this unfavorable spot, develops a stolon of greater length.

\section{CORYNOTRYPA DELICATULA (James).}

Hippothoa delicatula James, Paleontologist, no. 1, 1878, p. 6.

Stomatopora delicatula Nickles and Bassler, Bull. U. S. Geol. Surv., no. 173, 1900, p. 419.-Bassler, Proc. U. S. Nat. Mus., vol. 30, 1906, p. 55, pl. 3, figs. 4-7.

Stomatopora proutana Miller, Journ. Cincinnati Soc. Nat. Hist., vol. 5, 1882, p. 39, pl. 1, figs. 4-4b.-Ulrich, Geol. and Nat. Hist. Surv. Minnesota, Final Rep., vol. 3, pt. 1, 1893, p. 117, pl. 1, figs. 8-12.

Rhopalonaria pertenuis UlRICH, Fourteenth Ann. Rep. Geol. and Nat. Hist. Surv. Minnesota, 1886, p. 59. 
Stomatopora tenuissima Ulrich, Journ. Cincinnati Soc. Nat. Hist., vol. 12, 1890, p. 175, fig. 2; Geol. and Nat. Hist. Surv. Minnesota, Final Rep., vol. 3, pt. 1, 1893, p. 116, pl. 1, figs. 16, 17.

Stomatopora delicatula-tenuissima Nickles and Bassler, Bull. U. S. Geol. Surv., no. 173,1900 , p. 419.
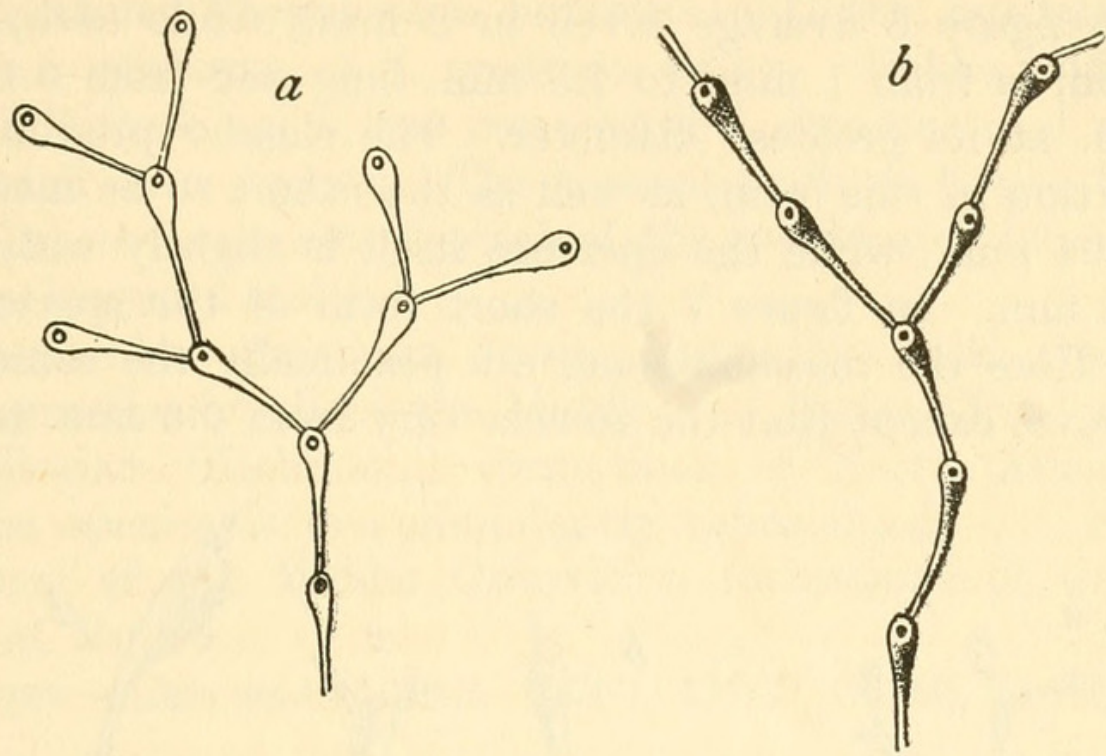

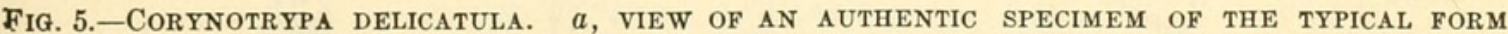
X12, incrusting a ramose bryozoan. Ordovician, Economy beds of Eden formation, CinCINNATI, OHIO; $b$, PART OF a ZOARIUM, $\times 12$, GROWING UPON THE EPITHECA OF AN EXPlaNATE BRyozoan. Ordovician, Ottosee shale, Knoxville, Tennessee.

Original description."Polyzoary creeping, adnate, branching dichotomously, and sometimes anastomosing. Branches linear, about one-tenth of a line in diameter. Cells uniserial, each growing by a pointed base from the cell below, and expanding gradually to the mouth; two or three cells in the space of a line. Apertures terminal, elevated, and nearly or quite the diameter of the cells and placed on their front face."

To James's original description the following remarks may be added. Strictly speaking, the zoœcia do not gradually expand from a pointed
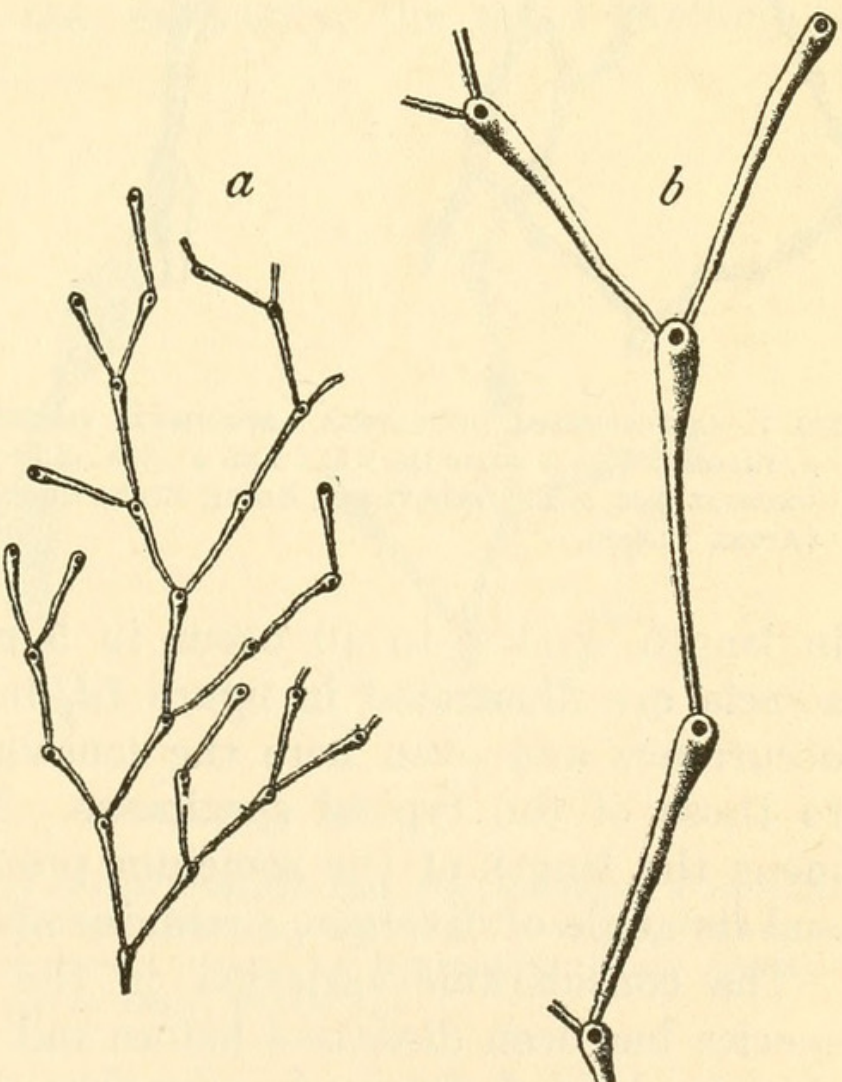

Fig. 6.-CoRynotrypa DELicatula, $a$ AND $b$, the tyPeSPECIMEN OF STOMATOPORA TENUISSIMA, $\times 9$ AND $\times 25$. Ordoviclan, ECONOMY BEDS OF EdEN Formation, CiNCinNati, OHio. (AFter Ulrich.)

base, but, as indicated in the several sets of figures illustrating this species, the slender part of the zoœcium, here styled the 
stolon, is of uniform diameter for some distance in the elongated forms. The gradual increase in diameter begins with the zoœecium proper. The dimensions for the various forms of the species are as follows: The zoœcia in the slender, elongate form shown in figure 6 average seven in $8 \mathrm{~mm}$., while each, including the stolon, is from $1 \mathrm{~mm}$. to $1.5 \mathrm{~mm}$. long and from $0.11 \mathrm{~mm}$. to $0.18 \mathrm{~mm}$. at its greatest diameter. The slender proximal or stolonal portion in this form, as well as the others to be mentioned, is about $0.04 \mathrm{~mm}$., while the aperture itself is slightly wider, averaging $0.05 \mathrm{~mm}$. In figure 7 the short form of the species is illustrated. Here the measurements are practically the same as those given above, except that the zoœcia vary from $0.6 \mathrm{~mm}$. to $0.8 \mathrm{~mm}$.
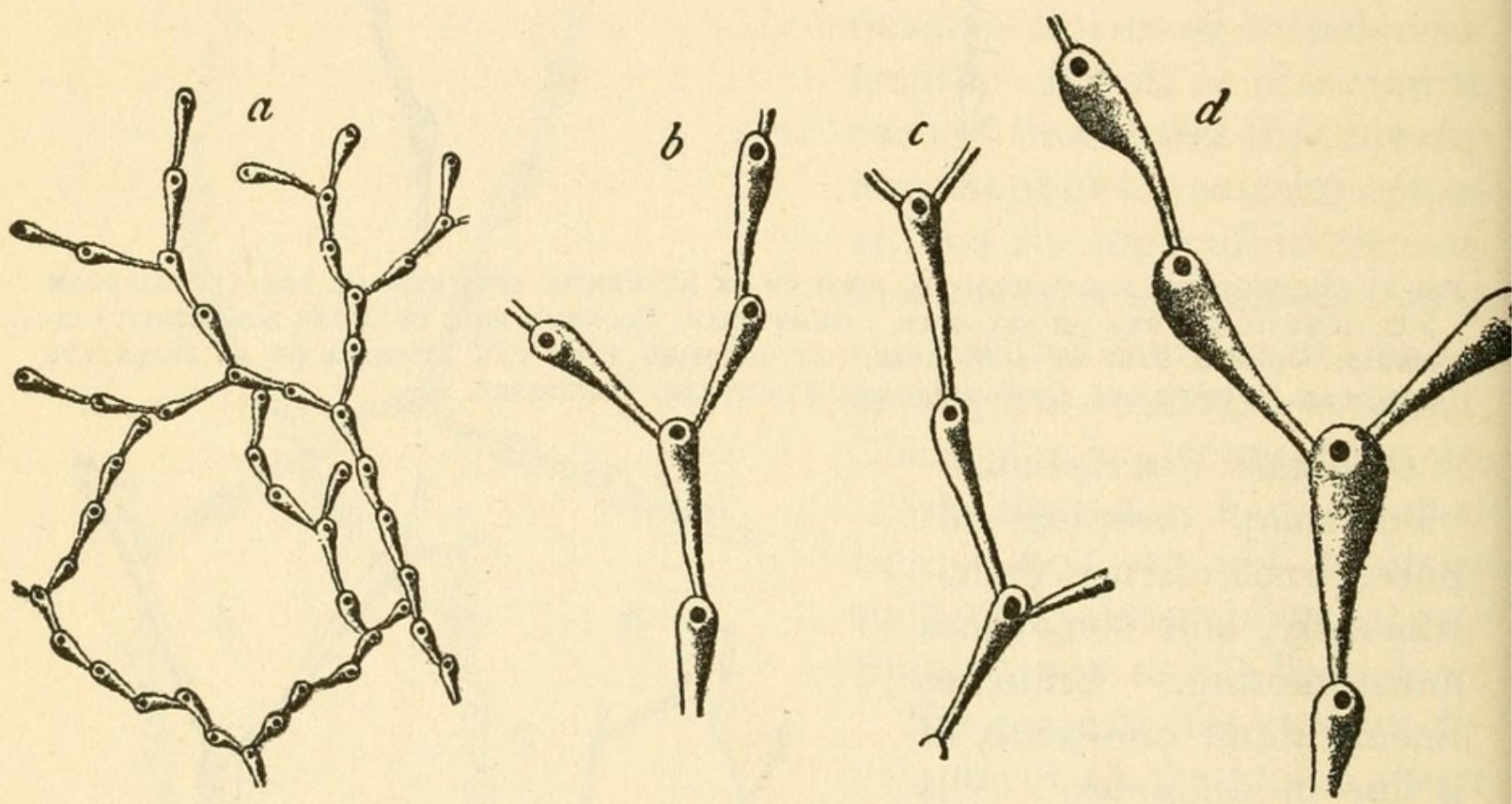

Fig. 7-Corynotrypa delicatula. Specimens figured by Ulrich as Stomatopora proutana. $a$, FRAGMENT OF A ZOARIUM, $\times 9 ; b$ AND $c$, TWO GROUPS OF ZOCECIA, $\times 25$; $d$, SEVERAL ZOGECIA OF unusual size, $\times 25$. Ordovician, Black River group, St. Paul and Minneapolis, Minnesota. (AFTER UlRich.)

in length, and 8 to 10 occur in $5 \mathrm{~mm}$. Several unusually large zoœcia are illustrated in figure $7 d$, but such specimens are of rare occurrence and even here the measurements are all in proportion to those of the typical specimens. In all of these various specimens the length of the zoœcium proper is approximately the same and its angle of divergence remains about $15^{\circ}$.

The considerable variation in the length of the stolon of this species has been discussed before and specific differences based upon this character have not been maintained, as noted in the synonymy above. At certain horizons, particularly in the McMillan formation at Cincinnati, Ohio, very luxuriant growths of $C$. delicatula are found and it in such specimens that the greatest variation is exhibited. 
Miller applied the name Stomatopora proutana to the very elongate form from the Corryville bed at Cincinnati, while specimens with the same characters but coming from the lower part of the Eden shale were described as $S$. tenuissima by Ulrich. The form with short zoœcia was named Rhopalonaria pertenuis by Ulrich, but later placed by him as a synonym of $S$. proutana Miller. Nickles and Bassler recognized James's name, but considered S. tenuissima of sufficient value to rank as a variety. The present study indicates that this last form has the zoœcium typical of the species and differs only in its greatly elongated stolon.

Occurrence.-An abundant fossil, beginning with the Stones River, in practically all of the Middle and Upper Ordovician and earliest Silurian (Richmond) formations of North America. In Europe the species is less abundantly represented, but is known from several of the Middle Ordovician formations of the Baltic provinces of Russia.

Plesiotypes.-Cat. nos. 13615, 43260, 43263, 54156, 54165, 54199, U.S.N.M.

\section{CORYNOTRYPA BARBERI, new species.}

At first sight this new species seems to be only an exceptionally large form of $C$. delicatula, but upon closer inspection other differences may be noted. These are, especially, the rapid swelling of
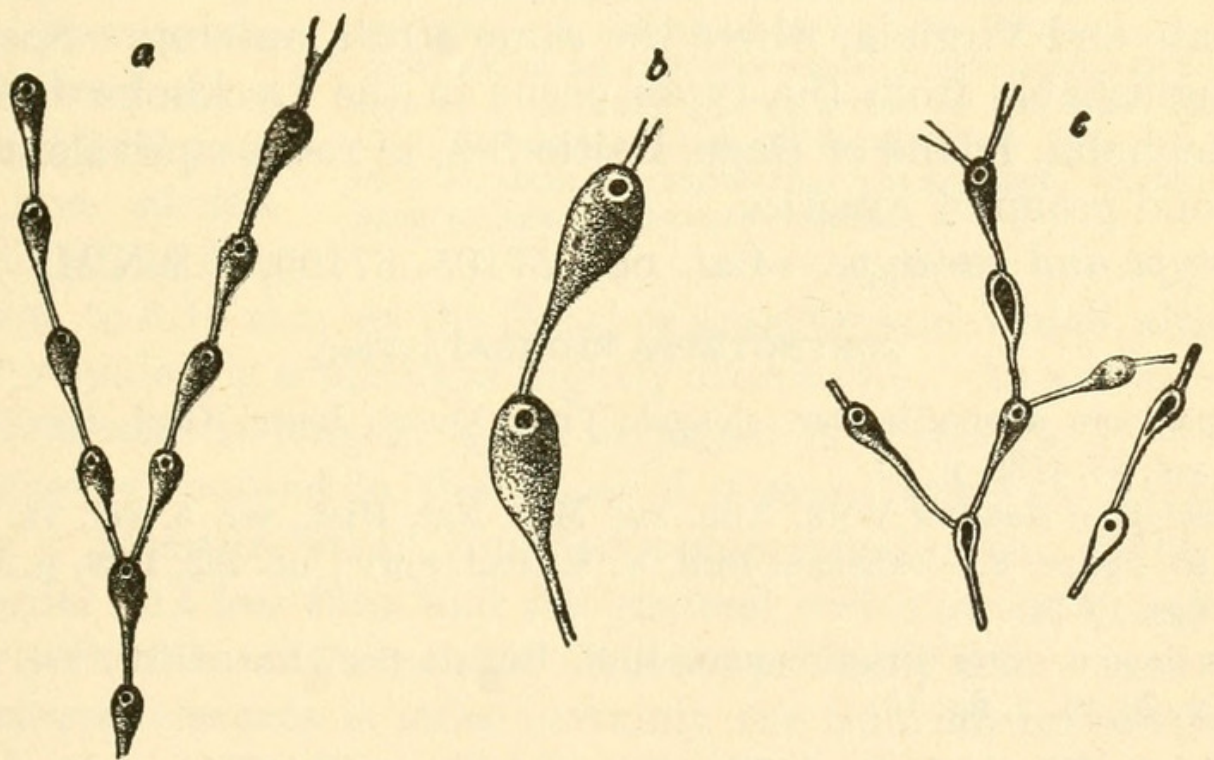

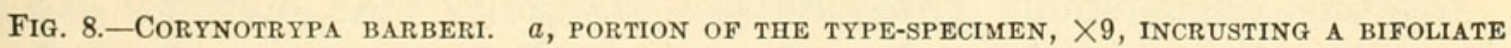
BRyozoan; $b$, Several zoceia, $\times 20$. Ordovician, OtTosee formation, KNoxville, Tennessee. c, PART OF a sMall COLONY, $\times 9$, growing UPON A species of Heliolites. Early Silurian, Lyckholm formation, Hohenholm, Island of Dago, Baltic Sea.

the zoœcia after the stolonal portion has been left behind, and the marked difference between the stolon and the zoœcium proper. In C. delicatula the angle of divergence is so small $\left(15^{\circ}\right)$ and the increase in the zoœcial diameter so gradual that it is difficult to discriminate 
between the stolon and the zoœcium proper. C. barberi, however, with equally slender and long stolons, has an angle of $30^{\circ}$, which is sufficient to cause the zoœcium to stand out prominently. Comparisons of equally magnified views of this and related species, as shown in figure 3 , indicate the unusually large size of the zoœcium in $C$. barberi, although its stolon has practically the same dimensions as the more delicate forms. The dimensions of the species are as follows: An average zoœcium, including the stolon, is $1 \mathrm{~mm}$. long and $0.23 \mathrm{~mm}$. wide at its greatest diameter. The angle of divergence, as noted before, is $30^{\circ}$.

In growth, relative position and size of apertures, and height of peristome, $C$. barberi differs in no way from other members of the $C$. delicatula section, although, because of its large angle of divergence, it may be regarded as approaching the $C$. inflata section. The species often forms very luxuriant growths upon massive bryozoans, brachiopods, and other organisms. Such zoaria, with their prominent although delicate zoœcia, form striking cabinet specimens.

The specific name is in appreciation of the excellent collections made in the vicinity of his home city by Mr. Manly D. Barber, of Knoxville, Tennessee.

Occurrence.-Common in the shales of the Holston and Ottosee formations at Knoxville, Tennessee, and at many other places in that state and Virginia, where the same strata outcrop. Specimens indistinguishable from the types occur in the Lyckholm formation at Hohenholm, Island of Dago, Baltic Sea, in rocks equivalent to the Richmond group of America.

Holotype and paratype.-Cat. nos. 57105, 57106, U.S.N.M.

CORYNOTRYPA ELONGATA (Vine).

Stomatopora dissimilis, var. elongata VIne, Quart. Journ. Geol. Soc. London, vol. 38,1882 , p. 50 .

Stomatopora elongata Vine, Ann. and Mag. Nat. Hist., ser. 5, vol. 14, 1884, p. 85, fig. Iv, 2.-BAssler, Bull. U. S. Geol. Surv., no. 292, 1906, p. 14, pl. 4, figs. 10-14.

Stomatopora parva Ringueberg, Bull. Buffalo Soc. Nat. Hist., vol. 5, 1886, p. 20, pl. 2, fig. 16 .

Original description.- "Stomatopora dissimilis Vine, var. a. elongata. Zoarium very irregular, clustering. Zoœcia elongated, with, at times, long stoloniferous processes which intermingle with the cells. When colonial growth is distinct, arrangement of cells is linear and uniserial. Measured under favorable circumstances, about three cells occupy the space of one line."

The present species has been treated by me at some length in the article cited above, and the following notes are mainly from that 
work. The identity of the American form with Vine's species has been determined by the study of an authentic example from the original Wenlock shales material studied by Vine. A few zoœcia of this example are shown in figure $9 a$, and comparison of this with the remaining figures of the American form indicates the specific identity. The long stoloniferous processes mentioned by Vine as intermingling with the cells are the stolons of ctenostomatous bryozoans such as Vinella or Ascodictyon, having no connection at all, of course, with Corynotrypa. Such widely diverse incrusting species are often found with their zoaria intermingled, but it usually requires little care to determine that one is merely growing over the other. The following description brings out the characters of $C$. elongata as observed in the present study.

Zoarium incrusting foreign objects, the smooth epitheca of corals or bryozoans being most frequently selected in the American examples. Zoœcia uniserial, branching at irregular intervals, slender, fusiform, increasing slowly in size from a diameter of $0.03 \mathrm{~mm}$. to $0.04 \mathrm{~mm}$. at the proximal end, to one

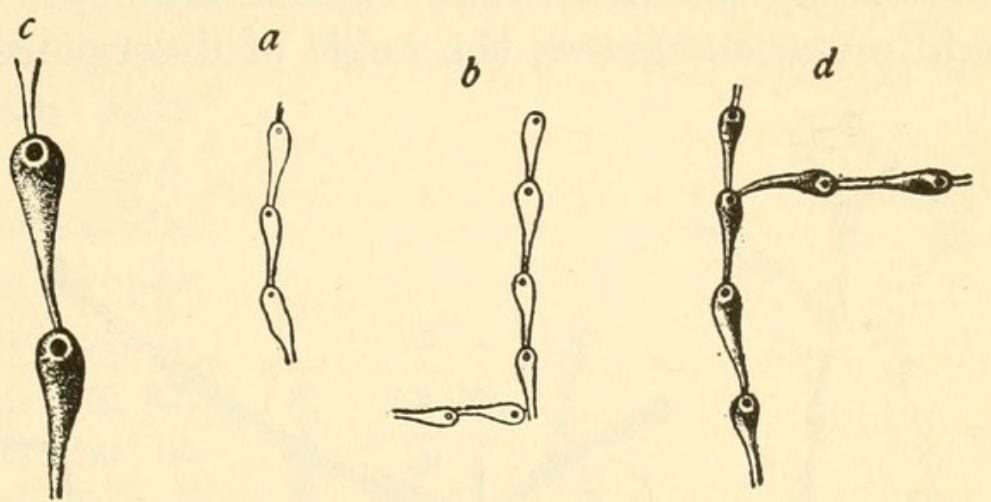

Fig. 9.-CORYNOTRYPA ELONGATA. $a$, SKETCH OF AN AUTHENTIC SPECIMEN, $\times 9$. Silurian (Wenlock), England; $b$, outline VIEW, $\times 9$, OF AN AMERICAN EXAMPLE INCRUSTING THE EPITHECAL SIDE OF A BRYOzOAN; $c$, TWO zofecia OF THE SAME, $\times 20$. SIlURiAN, Rochester SHALE, Rochester, New York. $d$, PORTion OF A ZOARIUM, $\times 12$, INCRUSTING A BRACHIOPOD. SILURIAN, WALDRON SHALES. IVALDRON, INDIANA.

of $0.15 \mathrm{~mm}$. to $0.18 \mathrm{~mm}$. at the distal or anterior end, which, although normally rounded, is sometimes slightly drawn out. An average zoœcium is $0.60 \mathrm{~mm}$. in length; when arranged in a straight line, seven zoœcia may be counted in the space of $4 \mathrm{~mm}$.; angle of divergence about $25^{\circ}$. Aperture small, rounded, subterminal, with a slightly elevated border and less than half the greatest width of the zoœcium in diameter. Surface of the zoœcia smooth, probably finely porous.

Corynotrypa elongata is most certainly the Silurian representative of the abundant Ordovician $C$. delicatula, from which it differs mainly in its increased angle of divergence.

Occurrence.-Somewhat rare in the Buildwas beds of the Wenlock shales, Shropshire, England; Clinton formation, Seven Mile Creek, near Eaton, Ohio; Rochester shale, Rochester and Lockport, New York; Waldron shale, Newsom, Tennessee, and Waldron, Indiana.

Plesiotypes.-Cat. nos. 35475, 57107, U.S.N.M. 


\section{CORYNOTRYPA NITIDA, new species.}

This very delicate, dainty species is clearly a descendant of the Ordovician type of the genus, C. delicatula (James), and of the widespread Silurian form, $C$. elongata (Vine). Indeed, these three forms are so similar that it is difficult if not impossible to point out striking differences. Very conservative students would probably regard the three as merely varieties, if not the same species, but, in view of their different geologic ages, and of the fact that some differences, however slight, may be observed, it is believed that the retention of separate specific names is preferable.

The incrusting zoarium of $C$. nitida has so far been noted only on corals, the two type-specimens growing upon Pachypora fischeri and Cystiphyllum americanum, respectively. The zoœcia are very slender and much elongated, the angle of divergence being about $20^{\circ}$. An
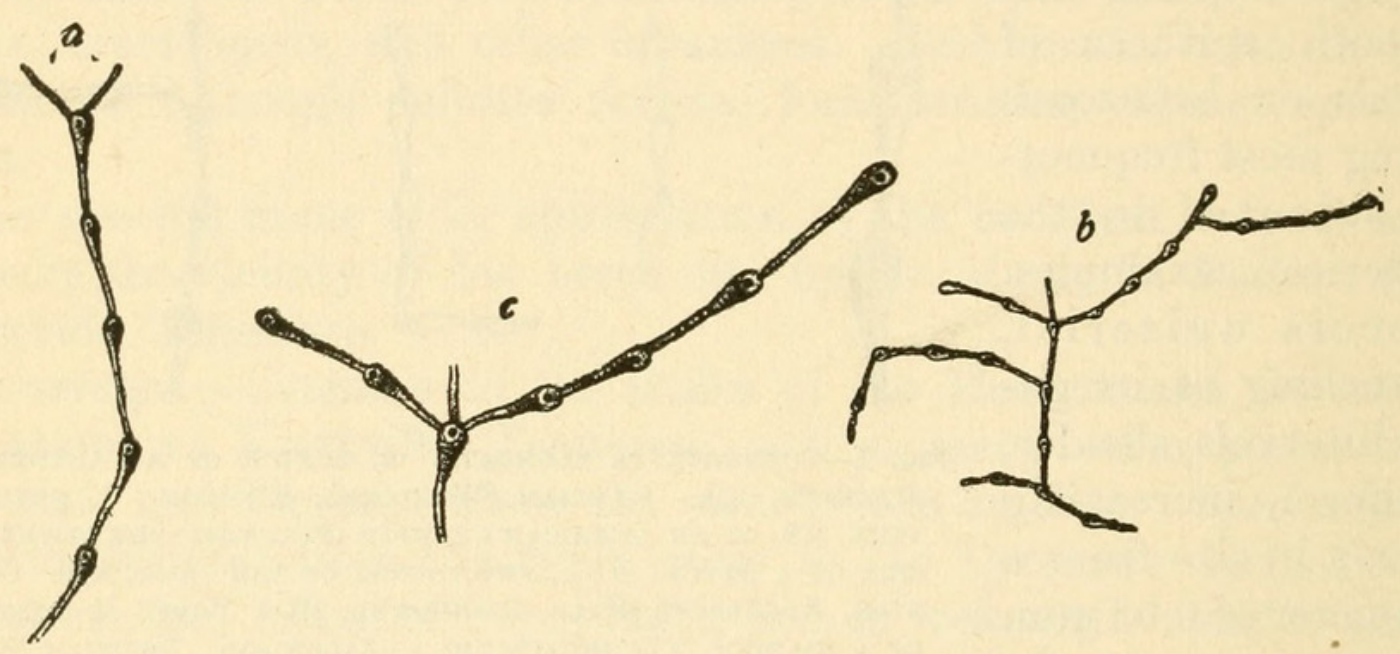

Fig. 10.-CORYNOTRYPA NITIDA. $a$, PORTION OF A ZOARIUM, $\times 20$, GROWING UPON THE CORAL Pachypora frondosa. Devonian, Hamilton group, Arkona, Ontario. $b$, sketch of a zoARIUM, $\times 9$, incrusting a CUP CORAL; $c$, Several zofela of the same, $\times 20$. Same HORIZON AT THEDFORD, ONTARIO.

average zoœcium, including the stolon, is $0.5 \mathrm{~mm}$. long and $0.07 \mathrm{~mm}$. across at its widest part, and 6 to 7 zoœcia may be counted in $3 \mathrm{~mm}$. The aperture is subterminal and constricted, about one-third the diameter of the zoœcium, and bears a low rim.

Compared with its Silurian progenitor, C. elongata, the present form is found to be decidedly smaller and more delicate and to have a less rapid angle of divergence. In general shape C. delicatula is probably more closely related, but here again the zoœcia, although delicate, are coarser in every measurement than in $C$. nitida.

Occurrence.-Apparently rare in the shales of the Hamilton group at Thedford and Arkona, Canada.

Cotypes.-Cat. nos. 54180, 54181, U.S.N.M. 


\section{CORYNOTRYPA TENUICHORDA (Ulrich and Bassler).}

Stomatopora tenuichorda (temnichorda in error) Ulrich and BASSLER, Geol. Surv. New Jersey, Paleontology, vol. 4, 1907, p. 314, pl. 20, figs. 5, 6.

Original description.- " Zoarium adnate, frequently branching, consisting of uniserially arranged zoœcia. Zoœcia elongate-pyriform, or club-shaped, $0.45 \mathrm{~mm}$. to $0.75 \mathrm{~mm}$. in length, about $0.02 \mathrm{~mm}$. in width at the posterior extremity, increasing very gradually in size through about one-half their length, and then somewhat abruptly to about $0.15 \mathrm{~mm}$. at the rounded anterior end. Zoœecial aperture nearly terminal, small, circular, with a slightly elevated, rim-like border, from $0.035 \mathrm{~mm}$. to $0.05 \mathrm{~mm}$. in diameter."

This delicate species is represented in the collections of the National Museum by a number of specimens, a portion of the best preserved one of which is shown in figure 11. While the general aspect of the species is precisely the same as in others of the $C$. delicatula group, a slight constriction in the middle portion of the zoœcium proper causes a noticeable swelling in its proximal portion, giving an appearance somewhat similar to that often seen in certain forms of Hippothoa. None of the specimens shows any other features characteristic of Hippothoa, and all agree with Corynotrypa in every respect save the one character mentioned. Until more evidence is at hand, the species may be regarded as a typical Corynotrypa, differing from the other
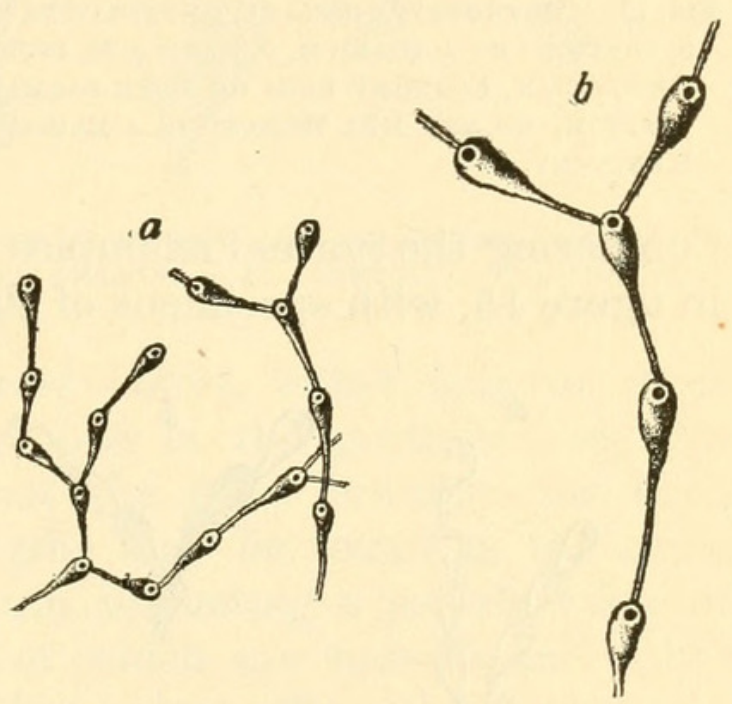

Fig. 11.-CORYNOTRYPA TENUICHORDA. $a$, PORTION OF A WELL PRESERVED ZOARIUM, $\times 9$, INCRUSTING THE INTERIOR OF A PELECYPOD; $b$, ZOCECIA of the same zoarium, $\times 20$. Cretaceous, VinCENTOWN SAND, VINCENTOWN, NEW JERSEY. narrow, elongate species in having a greater angle of divergence $\left(30^{\circ}\right)$, and in the proximal swelling of the zoœcia mentioned above.

Occurrence.-Not uncommon in the Vincentown sand of the Cretaceous, at Vincentown, New Jersey.

Holotype.-Cat. no. 52618, U.S.N.M.

CORYNOTRYPA INFLATA SECTION.

The angle of divergence obtaining in species assigned to the $C$. delicatula section is usually so small that the stolon and the expanded part of the zoœcium blend together to produce a structure which varies only in length. The variability in this section, therefore, although just as great, is not so conspicuous as in the $C$. inflata

Proc.N.M.vol.39-10-35 
section, where a wider angle of divergence results in a more expanded zoœcium, contrasting sharply with the narrow, tubular stolon.
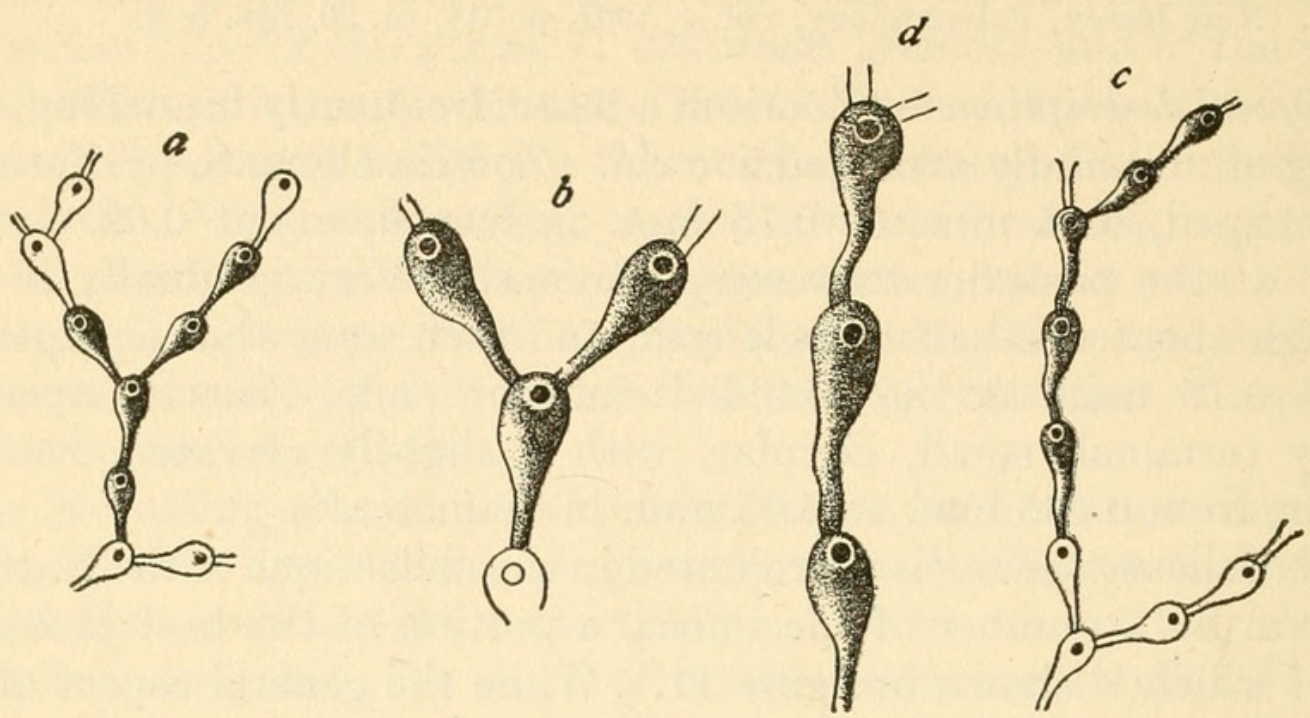

Fig. 12.-CORYNOTRYPA INFLATA, ILLUSTRATING DEVELOPMENT OF UNUSUALLY LONG STOLONS. $a$ AND $b$, PORTIONS OF A ZOARIUM, $\times 9$ AND $\times 20$, INCRUSTING THE BRACHIOPOD RAFINESQUINA SQUAMULA. ORdovician, ECONOMY BEDS OF EDEN FORMATION, Fort THOMAS, KENTUCKY. $c$ AND $d$, ANOTHER ZOARIUM, $\times 9$ AND $\times 20$, INCRUSTING A RAMOSE BRYOZOAN. SAME HORIZON AT WEST COVINGTON KENTUCKY.

Comparing the normal examples of $C$. inflata, for instance, as shown in figure 15 , with specimens of the same species possessing elongated
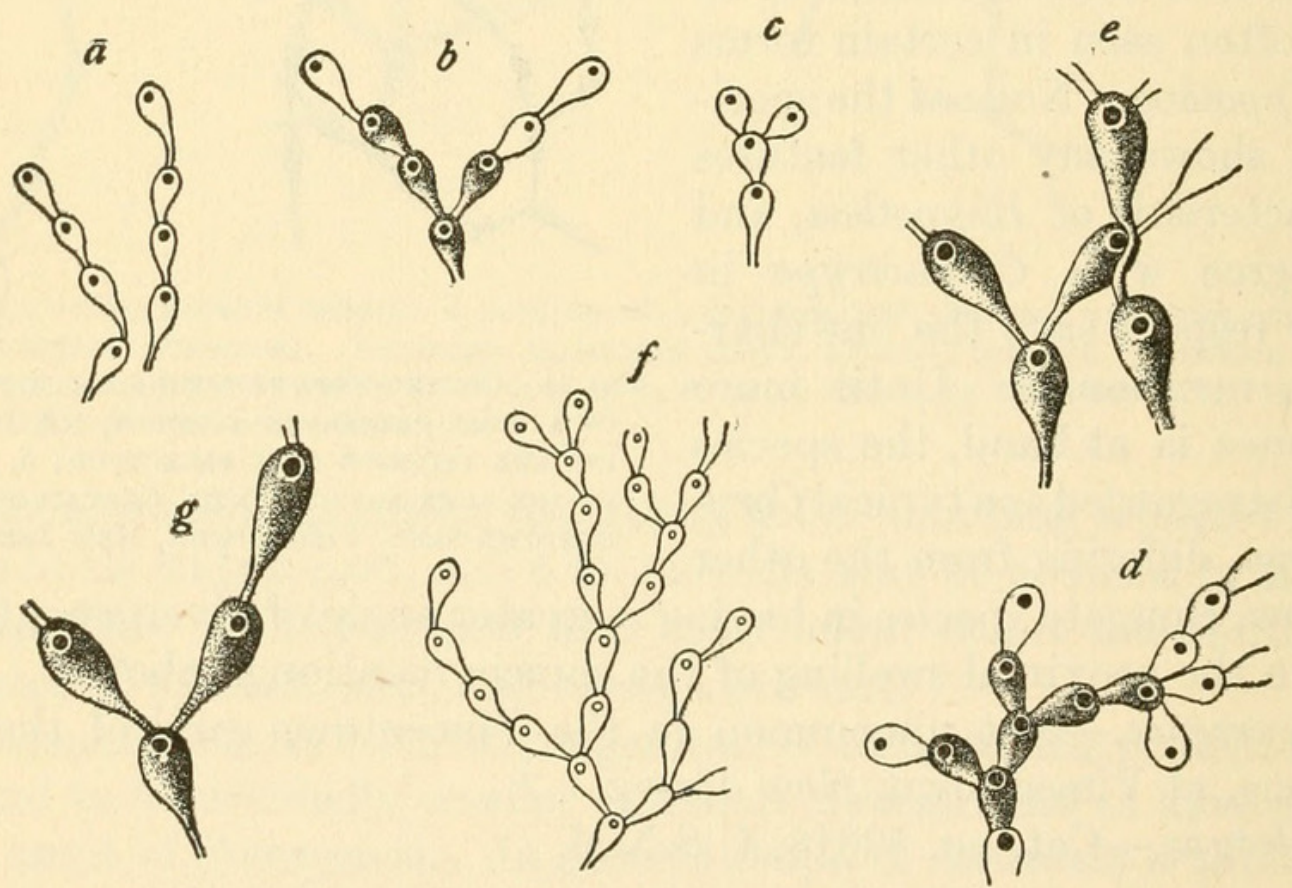

Fig. 13.-Corynotrypa inflata, illustrating variable length of stolons. $a, b$, AND $c$, THREE PORTIONS OF THE SAME ZOARIUM, $\times 9$, INCRUSTING THE PEDICLE VALVE OF STROPHOMENA trentonensis. Ordovician, Trenton formation, Zygospira beds, St. Paul, Minnesota. $d$, ANOTHER ZOARIUM, $\times 9$, With UNUSUALLy SHORT STOLONS, Black RIVER GROUP, PHYLlOporina bed, near Cannon Falls, Minnesota. $e$, zoccia, $\times 20$, with unusually long stolons, GrowING UPON A FRAGMENT OF A TRILOBIte. ECONOMY BEDS OF EDEN Formation, NewPort, KenTUCKY. $f$ AND $g$, A ZOARIUM, $\times 9$, AND A PORTION, $\times 20$, inCRUSTING RAFINESQUiNA Alternata. UPPER beds OF the EDEN FORMATION, CincinNati, OHIO.

stolons (fig. 12), one might, without a study of this individual variation, refer the two sets to separate species. In the typical forms of 
C. inflata, the stolon is quite short, in fact, often practically absent. The numerous examples before me show that this condition may prevail as long as the surface incrusted by the delicate zoaria is fairly even and smooth. Such a surface is afforded by the brachiopods incrusted by the originals of figure 15 . The coarse striations of the brachiopod Rafinesquina squamula, incrusted by the originals of figs. $12 a, b$, produce a more uneven surface, and a similar surface is caused by the zoœcial apertures and acanthopores of the ramose bryozoan bearing the zoarium figured in $12 c, d$. The effect upon the length of the stolon is shown in the illustrations.

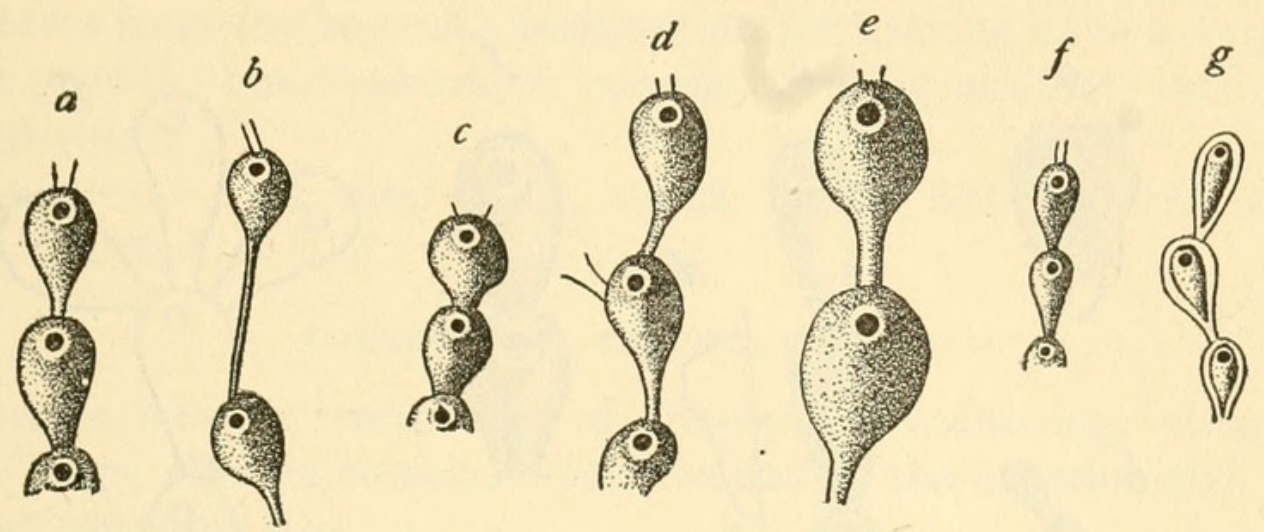

Fig. 14.-CoRynotrypa inflata Section. A group of zocecia, All $\times 20$, except possibly $g$, SHOWING SPECIFIC DiffERENCES. $a$, CorynotryPa inflata; $b$, C. ABRUPta; $c$. $c$. curta; $d$, C. MEdialis; $e$, C. TURGIDA; $f$, C. DEVoNiCA; $g$, C. SMITHI.

In each of the examples compared above, either long or short stolons have been uniformly developed in the portions used for illustration. Such uniformity is not the rule, however, for both extremes and all intermediate lengths may be found in the same zoarium. This is shown in a zoarium incrusting a pedicle valve of Strophomena trentonensis, portions of which are smooth and other parts rough (figs. 13a-c). In another colony (fig. 13d), incrusting the nearly smooth base of a Prasopora, the stolon is wanting practically throughout the entire growth. Figure $13 e$ illustrates the length of stolon attained when one zoœcium grows over another. Another zoarium bearing zoœcia with stolons of variable length is illustrated in figures $13 f$ and $g$.

Normal zoœcia of each of the species referred to the $C$. inflata section of Corynotrypa have been assembled in figure 14 .

\section{CORYNOTRYPA INFLATA (Hall).}

Alecto inflata Hall, Nat. Hist. New York, Pal., vol. 1, 1847, p. 77, pl. 26, figs. $7 a, b$.

Hippothoa inflata Nicholson, Pal. Ohio, vol. 2, 1875, p. 268, pl. 25, figs. 1-1b.

Stomatopora inflata Vine, Quar. Journ. Geol. Soc. London, vol. 37, 1881, p. 615.-

Ulrich Journ. Cincinnati Soc. Nat. Hist., vol. 12, 1890, p. 176, fig. 3c; Geol. and Nat. Hist. Surv. Minnesota, Final Rep., vol. 3, pt. 1, 1893, p. 117, pl. 1, figs. 13-21; Zittel's Textb. Pal. (Eng. ed.), p. 261, fig. 412B.-Simpson, Fourteenth Ann. Rep. State Geol. New York for the year 1894, 1897, p. 597, figs. 202-204.-Ruedemann, Bull. New York State Mus., no. 49, 1901 [1902], p. 12, pl. 1, figs. 2, 3.-Cumings, Thirty-second Ann. Rep. Dep. Geol. Nat. Res. Indiana, 1907, p. 886, pl. 32, figs. $1,1 a$ 
Zorium adnate, usually upon ramose or solid bryozoans or brachiopods; zoœcia typically short, pyriform, with the stolon but slightly developed; eight or nine zoœcia in $5 \mathrm{~mm}$.; angle of divergence averaging $40^{\circ}$. Exclusive of the stolon a single specimen is $0.4 \mathrm{~mm}$. long and $0.26 \mathrm{~mm}$. wide. The aperture has a distinct peristome, is direct, circular, about $0.09 \mathrm{~mm}$. in diameter, and situated near the anterior end.

The variability of this species has been noted in the previous remarks upon the section. Reference to the illustrations (figs. 12

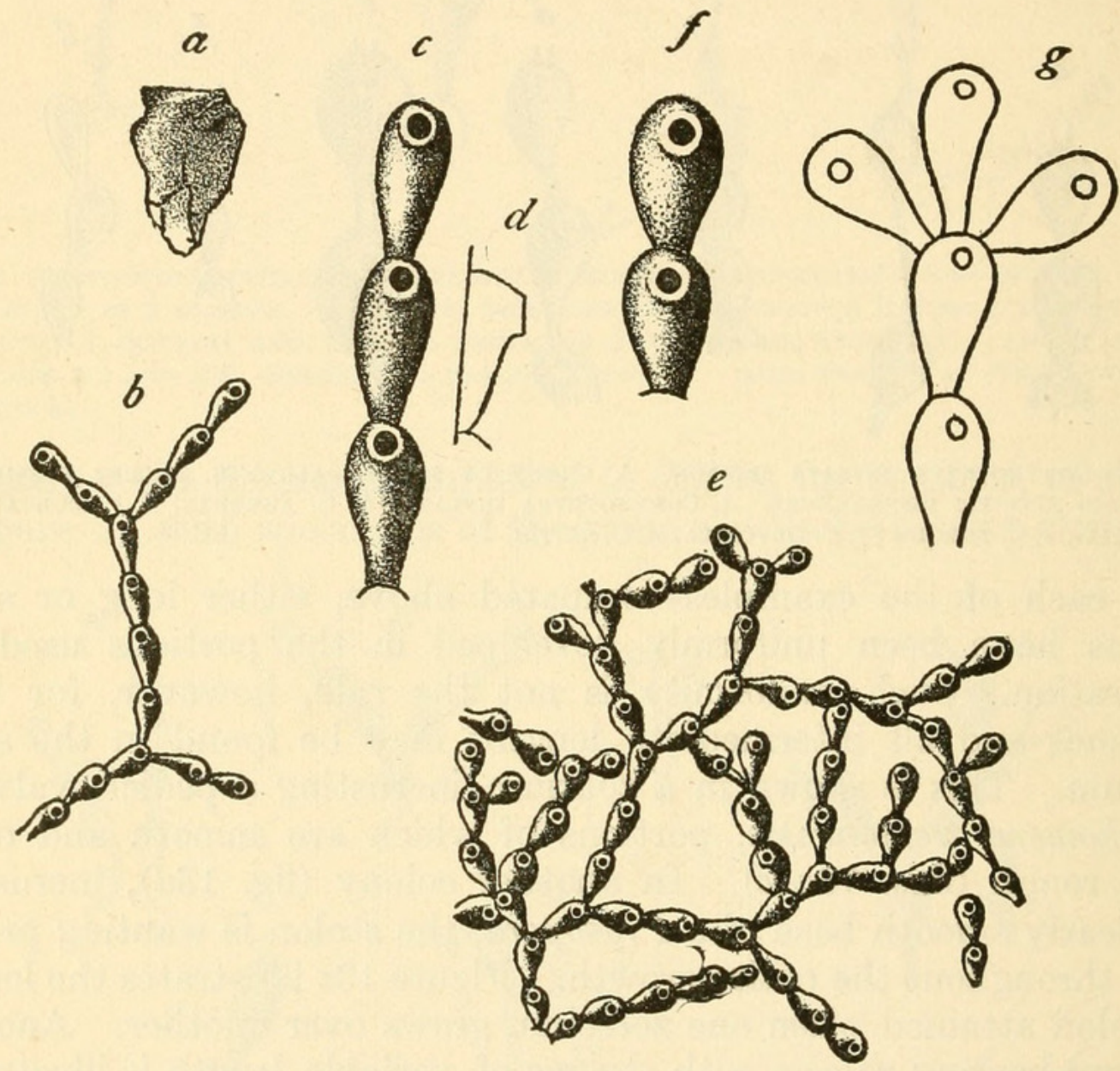

Fig. 15.-Corynotrypa inflata. $a$ and $b$, zoArium natural Size, and a portion, $\times 9$; $c$, three ZOđECIA OF SAME, $\times 18$, SHOWING THE POROUS WALL; $d$, A VERTICAL SECTION OF A ZOGECIUM, $\times 18$. UpPer third of the Trenton shales at CanNon Falls, Minnesota. $e$ and $f$, small portion OF A COLONY INCRUSTING RAFINESQUiNa ALternata, $\times 9$ AND $\times 18 ; g$, outLINE OF zOcEIA, $\times 18$, SHOWING THREE "GEMS" SPRINGING FROM ONE PARENT CELl. CORRYVILLE BEDS OF MCMILLAN formation, Cincinnati, Ohio. (After Ulrich.)

and 13) will show that the zoœcia of such variable zoaria are normal if the stolon is eliminated.

The pyriform shape and the size of the zoarium combined with its rather considerable angle of divergence, will distinguish $C$. inflata from related members of the section. The Devonian and Jurassic species, $G$. devonica and $C$. smithi, have a very similar zoarium, but in each instance their zoœcia, so far as present knowledge goes, are much smaller. The other members of the $C$. inflata section have 
greater angles of divergence and their zoœcia are therefore correspondingly more swollen.

Occurrence.--Specimens of $C$. inflata are generally abundant in all of the middle and upper Ordovician and earliest Silurian (Richmond) formations of North America. Recently its geographic range has been extended by the discovery of typical examples in the middle Ordovician (Wesenberg) limestone, at Wesenberg, Esthonia, Russia. The original types came from the Trenton rocks of New York, where the zoarium is of more delicate growth than in the higher formations. The forms from the several Cincinnatian formations have a very luxuriant growth, one network of zoœcia covering another until dense clusters result.

Plesiotypes.-Cat. nos. 43261, 43262, 54146, 54149, 54162, 54169, 54202, 57108, U.S.N.M.

\section{CORYNOTRYPA ABRUPTA, new species.}

Zoarium adnate, consisting of frequently branching, elongated, rather large, clavate zoœcia, much swollen at the anterior end. The tubular proximal stolonal portion is almost thread-like, being not more than $0.04 \mathrm{~mm}$. in width. This diameter is retained until the anterior third or fourth is reached, when the zoœcium abruptly swells, with an angle of divergence of $50^{\circ}$, and becomes rounded, with a diameter of 0.20 to
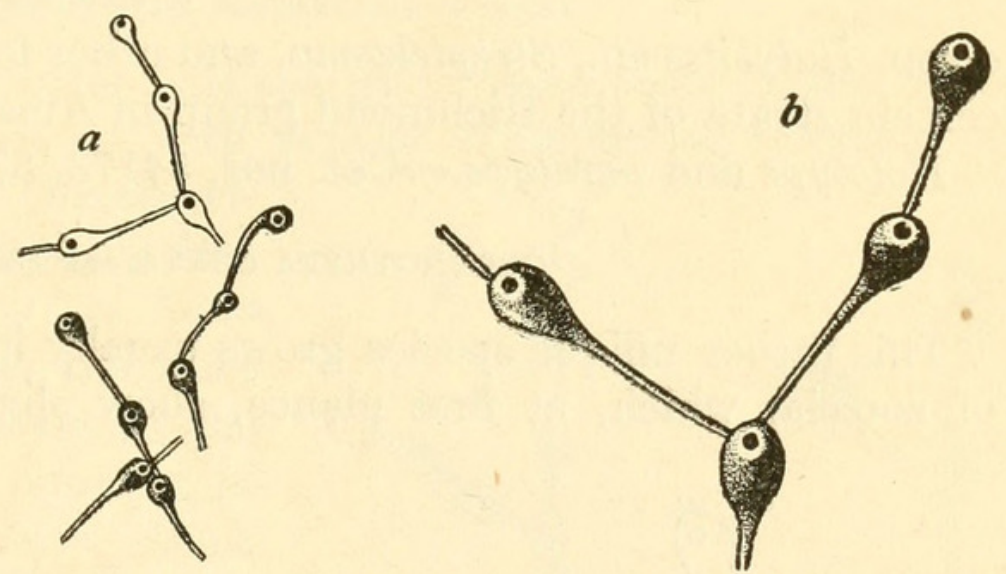

Fig. 16.-CORYNOTRYPA ABRUPTA. $a$ AND $b$, PORTIONS OF THE TYPE-SPECIMEN, $\times 9$ AND $\times 20$, INCRUSTING A FRAGMENT OF RHYNchotrema capax. Richmond group, Iron Ridge, Wisconsin.

$0.25 \mathrm{~mm}$. An average zoœcium and its stolon is $1.0 \mathrm{~mm}$. long, but in individual zoœcia of the same zoarium the thread-like proximal portion may range in length from less than $0.10 \mathrm{~mm}$. to $1 \mathrm{~mm}$. The swollen anterior zoœcial portion, however, is fairly constant in its measurements, as no deviation from a width ranging between $0.20 \mathrm{~mm}$. and $0.25 \mathrm{~mm}$., and a length of $0.32 \mathrm{~mm}$. to $0.40 \mathrm{~mm}$. has been observed. The apertures are round, subterminal, bordered by a slightly elevated rim, and small, averaging only about $0.09 \mathrm{~mm}$. in diameter.

Corynotrypa abrupta is easily distinguished from all other species of the genus by the extremely narrow proximal portion and the very abrupt swelling of the anterior end of the zoœcium. In related species such as $C$. inflata (Hall) and $C$. medialis, new species, the change from the proximal to the anterior end is less abrupt, but in 
the present form the two portions are most distinctly marked. The extreme variation in the length of the narrow proximal portion is noted above, and is indicative of the fact that this part of the zoœ-
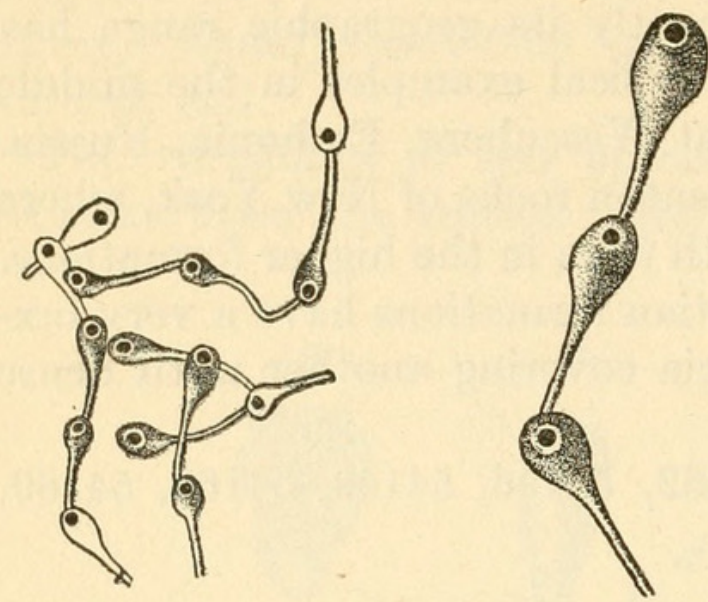

Fig. 17.-CORYNOTRYPA ABRUPTA. $a$ AND $b$, POR. TION OF A ZOARIUM, $\times 9$ AND $\times 20$, INCRUSTING A CRINOID COLUMN. EARLY SILURIAN, LyckHOLM formation, Kertel, Island of Dago, Baltic SEA. cium is the least stable in simple species of Cyclostomata.

Occurrence.-The American specimen illustrated in figure 16 , upon which the species is based, incrusts a fragment of Rhynchotrema capax and was found in the highest beds of the Maquoketa shale division of the Richmond group at Iron Ridge, Wisconsin. The Russian example assigned to the species (fig. 17) was found at Kertel, Island of Dago, in the Lyckholm limestone, associated with Calapoecia cribriformis Nicholson, Halysites sp., Streptelasma, and other fossils known to occur in certain strata of the Richmond group in America.

Holotype and paratype.-Cat. nos. 54173, 57109, U.S.N.M.

\section{CORYNOTRYPA CURTA, new species.}

This rather unique species grows usually in crowded little masses of zoœcia, which, at first glance, show slight resemblance to the

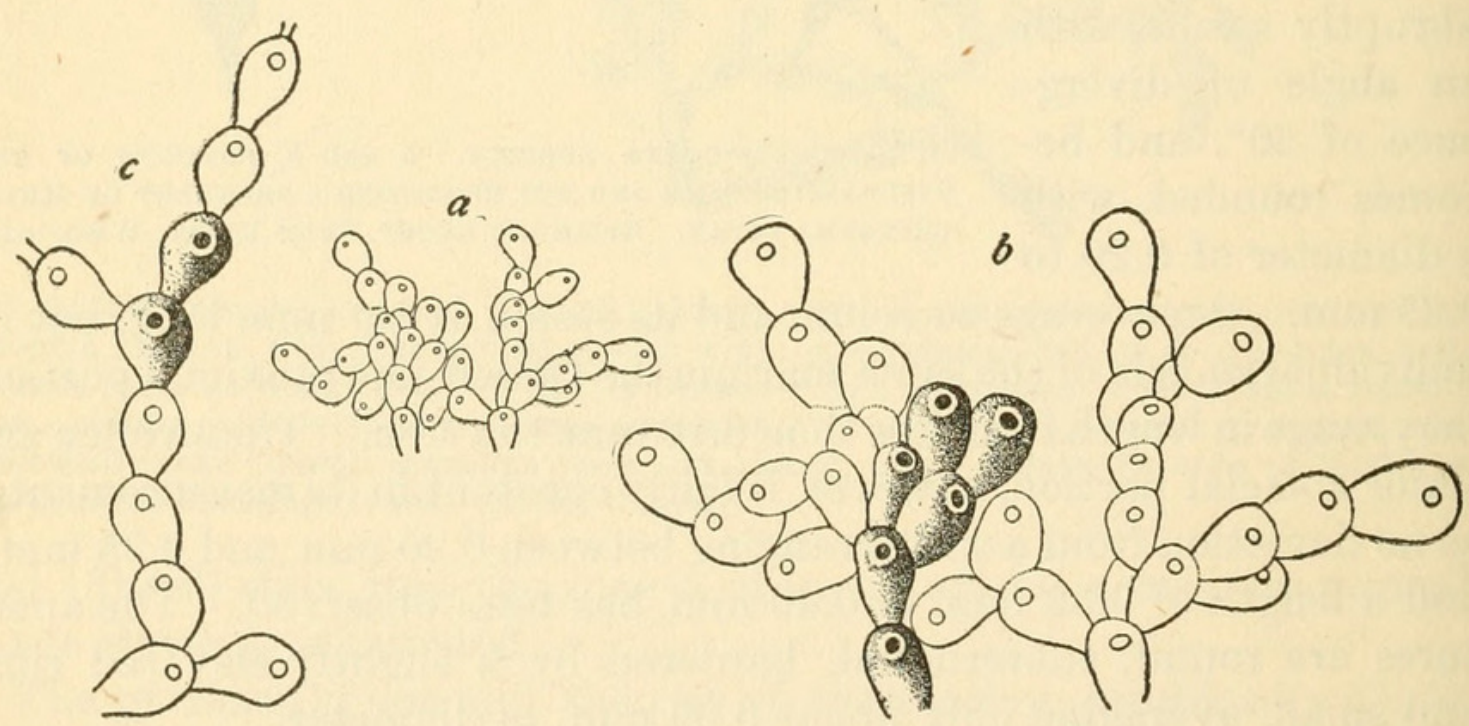

FIG. 19.-CORYNOTRYPA CURTA. $a$ AND $b$, PORTION OF A CROWDED ZOARIUM, X9 AND X20, INCRUSTING THE BRYOZOAN LIOCLEMELLA SOLIDISSIMA; $c$, FRAGMENT OF A ZOARIUM GROWING MORE NORmally, X20. Richmond GROUP. SAVANNaH, Illinois.

delicate, graceful colonies of other members of the genus. Upon resolving these small zoaria into their component zoœcia, it becomes 
evident that the crowded effect is produced by frequent budding of the short, almost rounded cells. A portion of such a dense growth is illustrated in figures $18 a, b$. Occasionally specimens with simple strings of zoœcia are found, and these show the intimate relationship of $C$. curta to the more common $C$. inflata.

Further comparisons with $C$. inflata will show the following differences: In $C$. curta the stolon is practically entirely absent, the zoœcium is small, but its angle of divergence is so great $\left(70^{\circ}\right)$ that the outline is subcircular or broadly oval. C. inflata has a larger and more pyriform zoœcium, a distinct although short stolon, and a much" smaller angle of divergence $\left(40^{\circ}\right)$. The other species of the genus are less closely related and will not need detailed comparison.

The measurements of a normal zoœcium in C. curta are: Length, $0.33 \mathrm{~mm}$.; greatest width, $0.26 \mathrm{~mm}$.; angle of divergence, $70^{\circ}$; six zoœcia in $2 \mathrm{~mm}$.

Occurrence.-Not uncommon in the upper beds of the Maquoketa shale division of the Richmond group at Savannah, Illinois.

Cotypes.-Cat. no. 54171, U.S.N.M.

\section{CORYNOTRYPA MEDIALIS, new species.}

The specimens upon which this species is based occur in the Richmond formation, associated with typical examples of Corynotrypa turgida and $C$. inflata. This association, in connection with the fact that the characters of $C$. medialis are intermediate between the other two forms, might give rise to the idea that the three are merely mutations of a single species. Such an idea is disproved, first by the constancy in the size of the zoœcium proper in each species, and second by the practical identity of the angle of divergence in separate individuals of the same species. The zoœcium of $C$. turgida is so much larger than that of $C$. inflata that one of intermediate size is

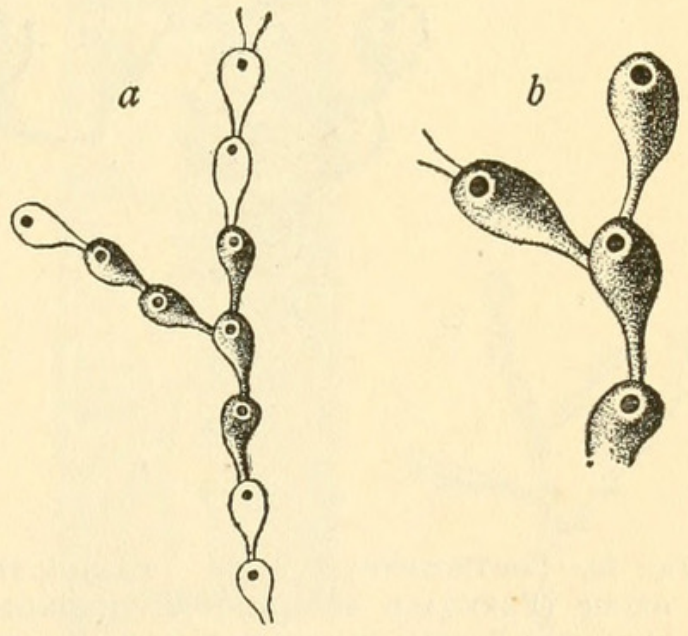

Fig. 19.-CORYNOTRYPA MEdiAlis. $a$, A PART OF THE TYPE-SPECIMEN, $\times 9$, INCRUSTING A CYSTID PLATE; $b$, SEVERAL ZOGECIA OF SAME, X20. RICHMOND GROUP, THREE MILES NORTH of SPRing VAlley, Minnesota.

still distinct enough to be easily recognized as different from each with even a low power hand lens. Normal zoœcia of these three species are contrasted in figure 14, while a portion of the specimen selected as the holotype is figured above. The variable length of the stolon is shown in figure $19 a$, although a greater variation may be expected on other examples.

The dimensions of the usual zoœcium of $C$. mediatis are as follows: Length of expanded portion, $0.50 \mathrm{~mm}$.; greatest width, $0.26 \mathrm{~mm}$.; 
average length of stolon, $0.17 \mathrm{~mm}$; four to four and one-half zoœcia in $3 \mathrm{~mm}$.; angle of divergence about $50^{\circ}$.

Occurrence.-Apparently rare in the Richmond group, 3 miles north of Spring. Valley, Minnesota.

Holotype.-Cat. no. 57110, U.S.N.M.

\section{CORYNOTRYPA TURGIDA (Ulrich).}

Stomatopora turgida UlRich, Journ. Cincinnati Soc. Nat. Hist., vol. 12, 1890, p. 176, fig. 3; Geol. and Nat. Hist. Surv. Minnesota, Final Rep., vol. 3, pt. 1, 1893, p. 118, pl. 1, figs. 22, 23.

Original description.- "Zoarium adnate, consisting of a single branching series of zoœcia. Zoœcia comparatively very large, the
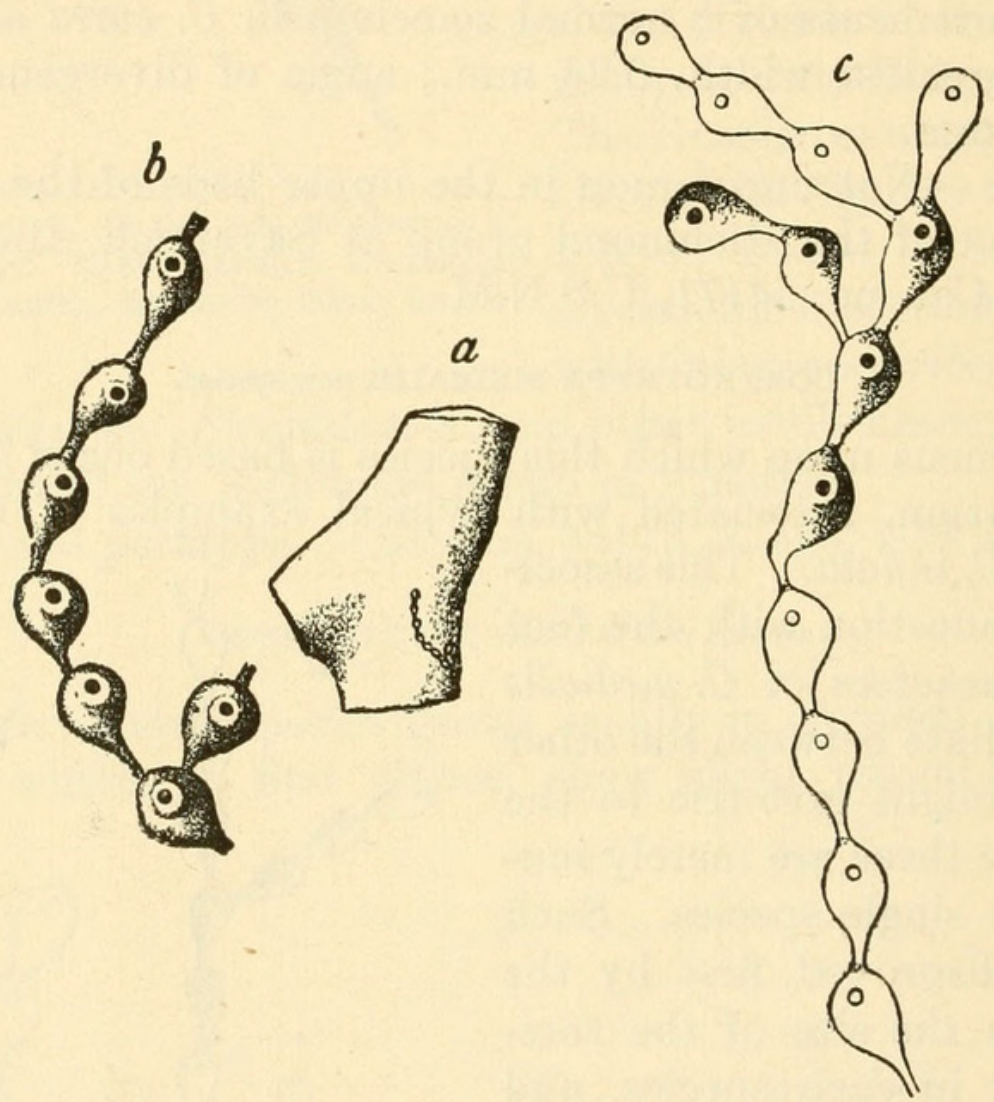

Fig. 20.-Corynotrypa turgida. $a$ AND $b$, the tYPE-SPECIMEN, NATURAL Size AND $\times 9$. Richmond group (Fernvale formation), Wilmington, Illinois. (After Ulrich.) c, a specimen, $\times 9$, From the Richmond group, 3 miles north of Spring VAlley, Minnesota.

anterior half much swollen, rapidly tapering posteriorly, with the slender, tubular proximal end inserted beneath the turgid anterior end of the preceding zoœcium. Five zoœcia in $5 \mathrm{~mm}$.; length of each zoœcium varying from 0.85 to $1.30 \mathrm{~mm}$; the greatest diameter of the anterior half from 0.4 to $0.6 \mathrm{~mm}$. The longest cells are the least turgid, while the shortest are the most. - Apertures round, bordered by an elevated margin, small, $0.1 \mathrm{~mm}$. in diameter, and situated about one-fourth of the length of the zoœcium from its anterior end." 
This species is represented in the collections of the U. S. National Museum by two excellent specimens from the type-locality, and by a third form from Minnesota, all of which agree with the description and measurements given above. The exceptionally large swelling of the zoœcia, and the very short and narrow stolonal portion are in such contrast that little difficulty should be experienced in recognizing the species. The amount of divergence of the zoœcium proper is about $50^{\circ}$. A similar abrupt swelling of the same region is present in $C$. curta and $C$. abrupta from the Richmond group, but each of these has zoœcia only one-third the size of those of $C$. turgida.

Occurrence.-Rare in the Richmond group (Fernvale shale) at Wilmington, Illinois, and in the same group at a locality 3 miles north of Spring Valley, Minnesota.

Plesiotype.-Cat. no. 54155, U.S.N.M.

CORYNOTRYPA DEVONICA (Oehlert).

Hippothoa devonica Oenlert, Bull. Soc. d'Etudes Scientifiques d'Angers, vol. 17, 1888, p. 104, pl. 10, figs. 2-2c.

This species is known to me only from Oehlert's illustrations, which are here reproduced. Judging from these figures and from the magnifications ascribed to them, $C$. devonica belongs to the C. inflata section of Corynotrypa, but differs in its conspicuously smaller size. $C$. inflata has eight or more zoœcia in $5 \mathrm{~mm}$., while fourteen to fifteen occur in the same diameter in $C$. devonica. It is probable that more careful study and illustrations of Oehlert's species will reveal other differences, although present knowledge is sufficient to place the form generically and to point out its specific relationships.

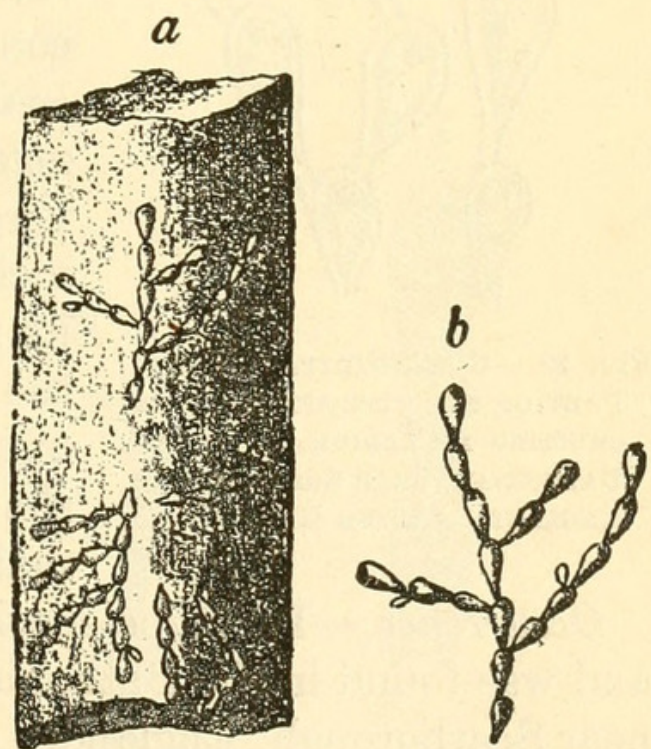

Fig. 21.-CORYNOTRYPA DEVONICA. $a$, ONE OF THE TYPE-SPECIMENS, $\times 7 ; b$, PORTION OF THE Same, $\times 12$. Devonian, Department de la Mayenne, France. (After Oehlert.)

Occurrence.-Devonian, La Baconniere, Department de la Mayenne, France.

\section{CORYNOTRYPA SMITHI (Phillips).}

Cellaria smithi Phillips, Geol. Yorkshire, pt. 1, Yorkshire Coast, 1829, p. 143, pl. 7, fig. 8.-Bean, Mag. Nat. Hist., ser. 2, vol. 3, 1839, p. 58.-WRIGHT, Quart. Journ. Geol. Soc. London, vol. 16, 1860, p. 28.

Hippothoa smithi Morris, Cat. Brit. Foss., 1843, p. 39; ed. 2, 1854, p. 125.Haime, Mem. Soc. Geol. France, ser. 2, vol. 5, 1854, p. 217.-Pictet, Traite Pal., ed. 2, vol. 4, 1857, p. 103. 
Alecto smithi D'Orbigny, Prodr. Pal., vol. 1, 1849, p. 317.

Stomatopora smithi Gregory, Rep. Yorkshire Philos. Soc., 1894, p. 58, fig. 1; Ann. and Mag. Nat. Hist., ser. 6, vol. 15, 1895, p.226; Cat. Foss. Bryozoa, The Jurassic Bryozoa, 1896, p. 56, fig. 8.

Gregory's description of this species follows:

Zoarium hippothoiform, uniserial; branches crowded and irregular; entirely adherent.

Zoœcia pyriform; long, slender, proximal ends; front wall well raised, rounded, and punctate; orifice small, circular, surrounded by a low rim.

Peristomes slightly raised. Flat, regular rims surround each of the zoœcia.

On account of the imperfection of Phillips's figures this species was not understood until Gregory described and refigured the typespecimen. As remarked by this author, the front walls of many zoœcia in this specimen are often broken away, giving it a schizoporellidan aspect. Gregory, however, fails to mention a most important matter, namely, the magnifica-

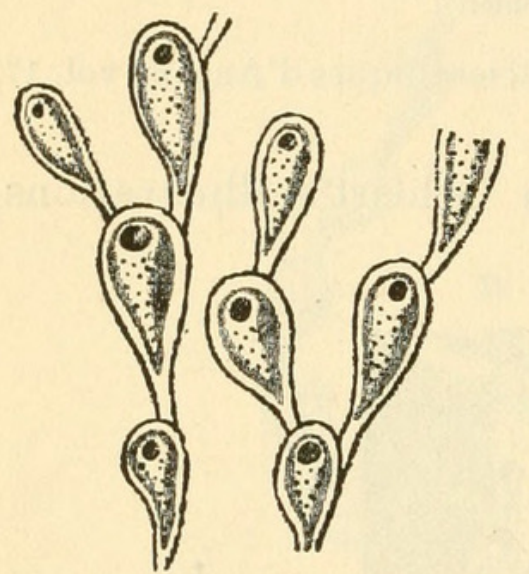

Fig. 22. - CORYNOTRYPA SMITHI. PART OF THE TYPE-SPECIMEN, INCrusting a Cardium. Jurassic, BATHONIAN, NEAR SCARBOROUGH, ENGLAND. (AFTER GREgory.) tion of his figure. Judging from other magnifications in his volume, the figure, which is herewith reproduced, is enlarged about 25 diameters, but until this point is accurately determined the species can not be considered as fully described. Stomatopora smithi is undoubtedly a member of Corynotrypa, and, judging from its angle of divergence $\left(40^{\circ}\right)$, is quite similar to the Ordovician $C$. inflata (Hall). Gregory has given its formula as $p, c, l, r=1,3,2,0$, but from the variation noted in other species, more numerous specimens of $C$. smithi would show only the first and fourth terms to remain constant.

Occurrence.-The type-specimen is incrusting Cardium citrinoidum and was found in the Bathonian (Cornbrash) division of the Jurassic, near Scarborough, England.

\section{CORYNOTRYPA DISSIMILIS SECTION.}

The four species assigned to this section form a less natural assemblage than those of the other two sections for the reason that they are either intermediate, in some of their characters, between Corynotrypa and Stomatopora, or show relationship to the other sections of Corynotrypa. The species selected as typical for the section has well-marked characters which are shared by only one other species, C. tennesseensis. These two forms constitute a small subsection characterized (1) by a slight proximal constriction of the zoœcium, giving a small angle of divergence, and (2) by an aperture which, in addition 
to being practically unconstricted, as in Stomatopora, tends also to be exsert, as in that genus. The proximal constriction of the zoœcium, although slight, allies the species to Corynotrypa, but the remaining characters are the same as in Stomatopora. The two remaining species of the section, $C$. schucherti and $C$. canadensis, are more nearly related to Corynotrypa, since they have more constricted apertures surrounded by a peristome. Their proximal constriction, however, is much as in $C$. dissimilis, so that they must be considered as intermediate forms.

CORYNOTRYPA DISSIMILIS (Vine).

Stomatopora dissimilis VIne, Quart. Journ. Geol. Soc. London, vol. 37, 1881, pp. 615, 616, figs. 1-8; vol. 38, 1882, p. 50.-Bassler, Bull. U. S. Geol. Surv., no. 292,1906 , p. 15 , pl. 4 , figs. $15-19$.

Stomatopora recta Ringueberg, Bull. Buffalo Soc. Nat Hist., vol. 5, 1886, p. 20, pl. 2, figs. 15, $15 a$.

Stomatopora minor Hennig, Arkiv für Zool., Kong. Sven. Vet.-Akad. Stockholm, vol. 3 , no. 10, 1906, p. 24, pl. 3, fig. 6 .

Aulopora, species, Hall, Nat. Hist. New York, Pal., vol. 2, 1852, pl. 50, figs. $27,29$.

Original description.- "Zoarium adnate, branching, generally attached to stems of Crinoidea, very rarely to broken shells; branches

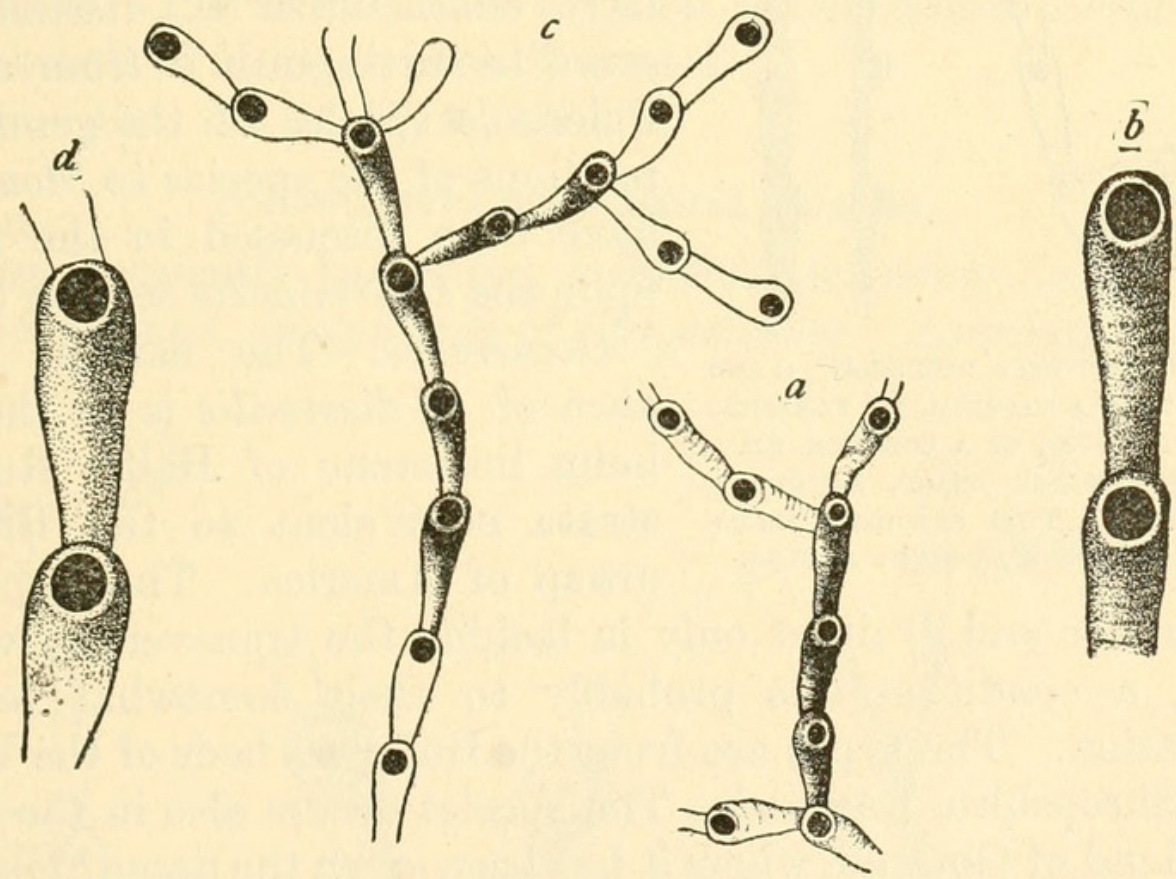

Fig. 23.-CoRynotryPa Dissimilis. $a$ AND $b$, A tYPiCAL EXAMPle of THE SPECIES, $\times 9$ AND $\times 20$, INCRUSTING THE EPITHECA OF the BRYozoAN Diplotrypa NUMMIformis. Silurian, Rochester

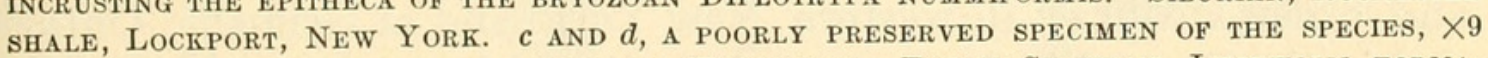
and $\times 20$, growing upon a specimen of Heliolites. Early Silurian, Lyckholm formation, Kertel, Island of Dago, Baltic Sea.

linear, sometimes wavy and anastomosing. Zooecia invariably uniserial, and, in the best preserved, very finely ribbed transversely; the oral extremity slightly raised; orifice circular or subcircular. Oœcial cells rather ventricose and strongly ribbed (?). Each normal zoœcium about half a line; average about 6 to $3 \frac{1}{2}$ lines." 
A series of specimens from the Silurian rocks of various localities in Europe and America shows that the Wenlock shales species described by Vine as Stomatopora dissimilis has as wide a geographic distribution as certain Ordovician species of Corynotrypa. As indicated in the above synonymy, the American form was figured by Hall in 1852 without a specific designation, and later was figured and described by Ringueberg as Stomatopora recta.

The zoarium of $C$. dissimilis is parasitic, other bryozoans, brachiopods, and crinoid columns or plates being usually selected; uniserial, with lateral series branching usually irregularly, but sometimes very regularly and at right angles to the main series, as shown in figure 24 . Zoœcia subcylindrical rather than club-shaped, about $0.10 \mathrm{~mm}$. in diameter at the proximal end and increasing to $0.35 \mathrm{~mm}$. at the

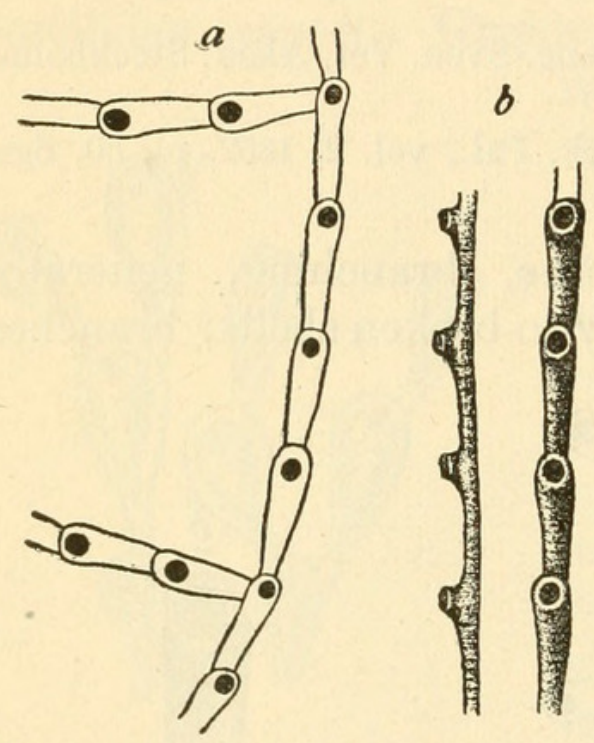

Fig. 24.-CORYNOTRYPA DISSIMILIS. $a$ AND $b$, PORTIONS OF A ZOARIUM, $\times 9$, PARASITIC UPON A FRAGMENT OF A SPIRIFER. SILURIAN, ROCHESTER SHALE, LOCKPORT, NEW YoRK. THIS SPECIMEN ILLUSTRATES BRANCHING AT RIGHT ANGLES. rounded distal portion; an average zoœcium is $1.15 \mathrm{~mm}$. in length. Apertures large, subterminal, slightly exsert. Zoœcia marked transversely by fine wrinkles or striations.

The large zoœcia with their transverse striations or wrinkles particularly characterize $C$. dissimilis and serve to distinguish it from all other Paleozoic species of the genus. The relations of the species to Stomatopora have been discussed in the remarks upon the C.dissimilis section (p. 522).

Occurrence.-The earliest appearance of $C$.dissimilis is in the Lyckholm limestone of Baltic Russia, in strata equivalent to the Richmond group of America. These specimens (see figs. $23 c$ and $d$ ) differ only in lacking the transversely wrinkled surface, a condition due probably to their somewhat imperfect preservation. The types are from the Buildwas beds of the Wenlock shales, Shropshire, England. The species occurs also in the Silurian beds, Island of Gotland, where it has been given the name Stomatopora minor by Hennig. It is abundant in the Rochester shale at Lockport and other localities in western New York, and at Grimsby, Ontario, and in the Osgood beds at Osgood, Indiana.

Plesiotypes.-Cat. nos. 35473, 57112, U.S.N.M.

\section{CORYNOTRYPA TENNESSEENSIS, new species.}

The two well-preserved specimens upon which this new species is based present a combination of characters so similar to those of C. dissimilis that the same description, with slight emendations, will 
apply to both. The characters in common are (1) rather large zoœcia with a slight angle of divergence and transversely lined or wrinkled walls, and (2) zoœcial apertures exsert as in Stomatopora and much larger than in typical Corynotrypa. Comparing the two closely, the average zoœcium of $C$.tennesseensis has a length of $0.75 \mathrm{~mm}$. and a width of $0.30 \mathrm{~mm}$. at its greatest diameter, and is therefore of less size than that obtaining in $C$. dissimilis.

The proximal constriction is also more pronounced in the older species, so that altogether it may be considered as representing an intermediate stage between the typical sections of

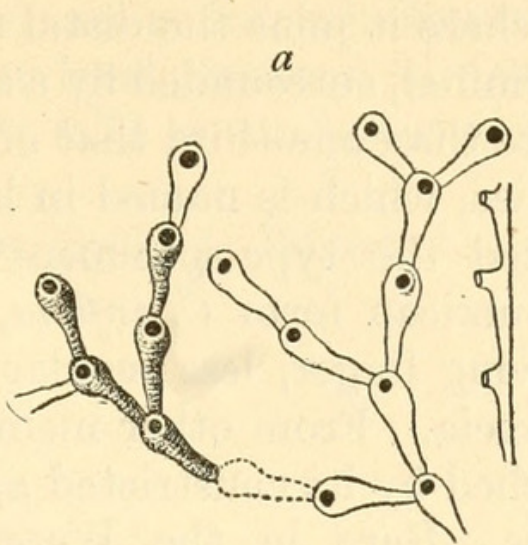

FIG. 25،-CORYNOTRYPA TENNESSEENSIS. $a$, THE TYPE-SPECIMEN, $\times 9$, WITH A LONGITUDINAL SECTION OF SEVERAL ZOGIA; $b$, SEVERAL ZOGECIA, $\times 20$, incrusting a Fragment of a Strophomena. Ordovician, Stones River group, Pierce limestone, one-half mile south of Murfreesboro, Tennessee.

Corynotrypa and the divergent group typified by $C$. dissimilis.

Occurrence.-Pierce limestone division of the Stones River group, $1 \frac{1}{2}$ miles south of Murfreesboro, Tennessee.

Cotypes.-Cat. no. 54177, U.S.N.M.

\section{CORYNOTRYPA SCHUCHERTI, new species.}

Zoarium frequently branching, uniserial, incrusting, in the case of the type-specimen, an example of Streptelasma. Zoœcium compara-
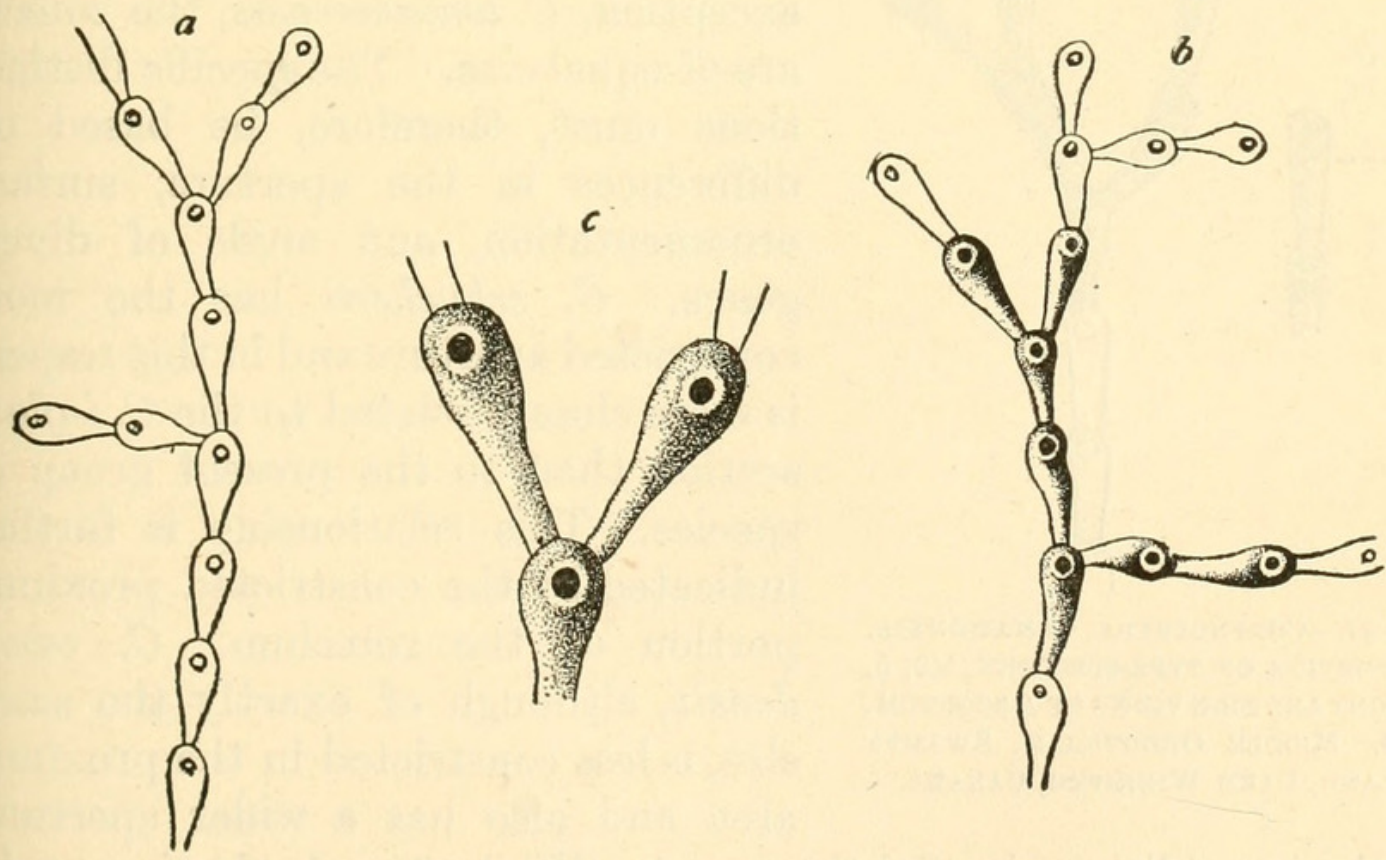

Fig. 26.-CoRynotrypa SCHUCHERTI. $a$ AND $b$, PORTIONS OF THE TYPE-SPECIMEN, INCRUSTING A Streptelasma, $\times 9 ; c$, Several zoceia of the same, $\times 20$. Middle Ordovician, Wesenberg Formation, WeSENBERG, Esthonia, Russia. 
tively large, averaging $1 \mathrm{~mm}$. in length, irregularly club-shaped, the anterior half swollen, with a maximum diameter of $0.40 \mathrm{~mm}$., tapering gradually in the posterior half to the narrowest part with a width of $0.15 \mathrm{~mm}$., where it joins the distal end of the preceding one. Apertures subterminal, surrounded by a slight border, and with a diameter slightly more than one-third that of the zoœcium.

This species, which is named in honor of Prof. Charles Schuchert, who collected the type-specimen, is related most closely to the common American form $C$. inflata, but differs conspicuously, however, in having larger, less regular, more elongate and less rapidly tapering zoœcia. From other members of the $C$. dissimilis group it is distinguished by its constricted aperture.

Occurrence.-Rare in the Wesenberg limestone at Wesenberg, Esthonia, Russia.

Holotype.-Cat. no. 57111, U.S.N.M.

\section{CORYNOTRYPA CANADENSIS (Whiteaves).}

Stomatopora canadensis Whiteaves, Pal. Foss., vol. 3, 1897, p. 161, pl. 18, figs. 4, $4 a$.

Through the courtesy of the Director of the Geological Survey of Canada, I am able to refigure the type of this species, which was well

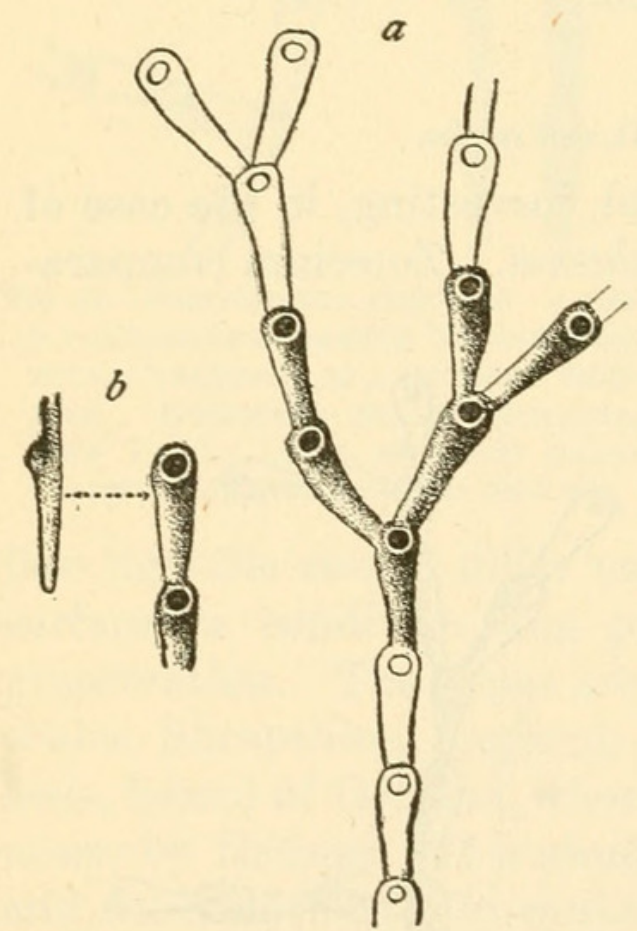

Fig. 27.-CORYNOTRYPA CANADENSIS. $a$, PORTION OF TYPE-SPECIMEN, $\times 9 ; b$, FRONT AND SIDE VIEWS OF A ZOCECIUM, $\times 9$. Middle ORdOVICIAN, SWAMPY IsLAND, LAKE WINNIPEG, CANADA. described by Professor Whiteaves, although his illustrations are inadequate for careful discrimination. Comparing figure 27 with figures 23 to 26 , the close relationship of these four species can not fail to be apparent. With one exception, C.tennesseensis, the zoœcia are of equal size. The specific distinctions must, therefore, be based on differences in the aperture, surface ornamentation, and angle of divergence. C. schucherti has the most constricted aperture and in this respect is more closely related to the $C$. inflata section than to the present group of species. This relationship is further indicated by the constricted proximal portion of the zoœcium. C. canadensis, although of exactly the same size, is less constricted in the proximal area and also has a wider aperture, which, in addition, is slightly exsert. While $C$. schucherti may be considered as intermediate between $C$. canadensis and $C$. inflata, C. canadensis likewise represents a stage between $C$. schucherti and $C$. 
dissimilis. C.tennesseensis, with its exsert aperture and transversely rounded zoœcia, is probably an early expression of the Silurian $C$. dissimitis.

The dimensions for $C$. canadensis are as follows: Average length of zoarium, $0.80 \mathrm{~mm}$.; width at constricted proximal portion, $0.22 \mathrm{~mm}$.; diameter at most expanded part, $0.37 \mathrm{~mm}$.; diameter of aperture, $0.20 \mathrm{~mm}$.

Occurrence.-Middle Ordovician, Swampy Island, Lake Winnipeg, Canada. 


\section{$2 \mathrm{BHL}$ Biodiversity Heritage Library}

Bassler, Ray S. 1911. "Corynotrypa, a new genus of tubuliporoid Bryozoa." Proceedings of the United States National Museum 39(1797), 497-527. https://doi.org/10.5479/si.00963801.39-1797.497.

View This Item Online: $\underline{\text { https://www.biodiversitylibrary.org/item/53443 }}$

DOI: https://doi.org/10.5479/si.00963801.39-1797.497

Permalink: https://www.biodiversitylibrary.org/partpdf/51989

\section{Holding Institution}

Smithsonian Libraries

\section{Sponsored by}

Smithsonian

\section{Copyright \& Reuse}

Copyright Status: Public domain. The BHL considers that this work is no longer under copyright protection.

This document was created from content at the Biodiversity Heritage Library, the world's largest open access digital library for biodiversity literature and archives. Visit BHL at https://www.biodiversitylibrary.org. 